\title{
Bir İslâm Âlimi Olarak Lutfi Paşa
}

\author{
A sım Cüneyd Köksal*
}

\section{Lutfi Paşa as a Religious Scholar}

Abstract Lutfi Pasha is one of the prominent statesmen in the 16th century Ottoman Empire. He performed several official duties during his career and served as grand vizier for two years, and authored several works, most of which are about Islamic sciences. He is famous for his political booklet, Asafname, but his books about Islamic sciences have not drawn the attention until now and remained as manuscripts. This article aims to examine Lutfi Pasha's scholarly works and evaluate him as an Islamic scholar.

Keywords: Lutfi Paşa, Islamic Sciences, Ahl-i Sunnat, Creed, Ilmihal, Caliphate, Kanun Register, Asafname, Asafnâme

\section{Giriş}

Lutfi Paşa (ö. 971/1564)1 Arnavut kökenli bir devşirme olarak II. Bâyezid zamanında saraya alınmış, Enderun'da tahsil görmüş, sancakbeyi, beylerbeyi ve vezir olmuş, Korfu seferinde Osmanlı deniz kuvvetlerine kumanda etmiş, Boğdan seferinde Mimar Sinan’ı padişaha takdim edip tanıtmış, iki yıl süreyle veziriazam olmuş, çeşitli idarî vazifeleri esnasında önemli görevler üstlenmiş bir devlet adamıdır. Veziriazamlıktan azledildikten sonraki hayatını telif ve araştır-

* İstanbul 29 Mayıs Üniversitesi

1 Lutfi Paşa’nın ölüm tarihi genel olarak 970/1563 olarak biliniyorsa da kendisinin 13 Ramazan 971/25 Nisan 1564 günü vefat ettiği, Süleymaniye Kütüphanesi, Esad Efendi 2142 numaralı mecmuadaki tarih kaydıyla tespit edilmiştir (M. Kemal Özergin, Sultan Kanuni Süleyman Han Çăğına Ait Tarih Kayıtları, Erzurum, 1971, s. 28). 
mayla geçirmiş, devlet adamlığının yanısıra yazdığı eserlerle de nam salmış bir şahsiyettir. ${ }^{2}$

Bir devlet adamı olarak yaptığı icraatlardan başka, Lutfi Paşa’nın bir müellif olarak bilinmesini sağlayan eser Âsafnâmèdir. Çok sayıda nüshası günümüze ulaşan eser üzerinde çeşitli çalışmalar yapılmış, Osmanlı devri siyasetnameleri içerisinde kendine özel bir yer edinmiştir. Bunun yanısıra bir Osmanlı tarihi olan Tevârih-i Âl-i Osman ile hilafet meselesini konu edinen Halâsül-Ümme adlı eserleri de yayımlanmış ve hakkında çalışmalar yapılmıştır. Ancak Lutfi Paşa'nın İslâmî ilimlere dair kaleme aldığı çok sayıda eser yayımlanmadığı gibi sözkonusu eserler incelenerek onun bu sahadaki mesaisini değerlendiren çalışmalar da yapılmamış, hatta eserlerinin tam bir envanteri dahi çıkarılmamış, şimdiye kadar kendi yazdığ 1 eserlere dair Tevârib'de kaydettiği liste tekrarlanmakla yetinilmiştir.

Bu makale Lutfi Paşa’nın eserlerine yakından bakmayı, bilhassa İslâmî ilimlerle ilgili eserlerini inceleyerek onun bu sahadaki mesaisi hakkında bir değerlendirme yapmayı ve bu eserler arasındaki ilişkiyi ortaya koymayı hedeflemektedir. Lutfi Paşa'nın eserlerine ait bulabildiğimiz nüshaları tespit ettik, kendisinin kayıtlarda ismi geçmeyen bazı eserlerine de ulaştık. Paşa’nın eserlerini incelemek suretiyle atıf yaptığı İslâmî ilimlere ait kaynakların bir listesini çıkardık. Ayrıca, bazı kaynaklarda kendisine nispet edilen "Kanunname" nin ne olduğuna ilişkin yazma halindeki iki siyasetnameye dayalı olarak bir değerlendirme yaptık.

\section{Lutfi Paşa’nın Eserlerine Yeni Bir Bakış}

Lutfi Paşa yirmi yıl kadar süren emeklilik hayatında kendini telif ve tetebbuya vermiş, Arapça ve Türkçe olarak çok sayıda eser kaleme almıştır. Tevârîh-i $\hat{A l-i}$ Osman isimli eserinin girişinde, o zamana kadar kaleme aldığ 1 eserlerin bir listesini verir. En meşhur eseri olan Âsafnâme’yi Tevârih'den sonra kaleme aldı̆̆ için buna listesinde yer vermez. Yayımlanmış olan Âsafnâme, Tevârih-i Âl-i Osman ve Halâsül-Ümme dışında irili ufaklı yirmiyi aşkın eseri İslâmî ilimlere dair olup bunlar arasında yalnızca Risâle-i Suâl ve Cevâb adlı küçük risalesi Kayhan Atik tarafından yayımlanmış, yine aynı araştırmacı Paşa'nın İslâmî eserlerinden

2 Mehmet İpşirli, "Lutfi Paşa”, DİA, XXVII/234-236. Lutfi Paşảnın hayatı hakkında ayrıca bkz. Fuat Köprülü, "Lutfi Paşa”, Türkiyat Mecmuası, 1925, sy. 1, s. 118-150; M. Tayyip Gökbilgin, "Lutfi Paşa”, İA, VII, 96-101. Tevarih'in tıpkıbasımına Serhan Tayşi'nin, Latin harflerine aktarılmış neşrine Kayhan Atik' in yazdıkları giriş yazıları büyük oranda zikri geçen makale ile maddeye dayanmaktadır. 
dördüne ait birer nüshayı tespit etmiştir. ${ }^{3}$ Yaptığımız araştırmalar neticesinde Lutfi Paşa'nın kaynaklarda ismi geçmeyen iki eserine ait birer nüsha tespit ettiğimiz gibi, Paşa’nın listesinde ismi geçmekle birlikte şimdiye kadar herhangi bir nüshasına ulaşılamamış eserlerinden dördüne ait nüshalar tespit edilmiş, ayrıca K. Atik'in birer nüshasına işaret ettiği eserlerden iki tanesine ait birer nüsha daha bulunmuştur. Lutfi Paşa'nın İslâmî eserlerine dair şimdiye kadar herhangi bir tez, monografi, değerlendirme, ayrıca bu eserler arasındaki ilişkiye dair bir tahlil yapılmamıştır. Çalışmamızın amaçlarından biri de, sözkonusu eserler üzerinde ileride yapılacak geniş çaplı araştırmalar için giriş niteliğinde bazı değerlendirmeler yapmaktır. Lutfi Paşa’yı bir âlim olarak değerlendirmeden önce, onun eserleri ve bu eserlerdeki muhteva üzerine eğilmemiz gerekmektedir. Zira onun ilim anlayışına ve âlim olma tarzına dair ifadelerimizi, eserleriyle ilgili yapacağımız gözlemlerden sonra söylememiz daha doğru olacaktır.

Lutfi Paşa Tevârih-i Âl-i Osman'ın girişinde ${ }^{4}$ eserlerini Arapça ve Türkçe olarak iki kısma ayırır. 13 Arapça ve 7 Türkçe eserin yer aldığı bu listeye göre Arapça kitapları şunlardır:

\section{Zübdetü'l-Mesâil fi'l-İ'tikādāt ve'l-İbâdât}

Nüshaları: Bayezid Devlet Kütüphanesi, no. 1985; Burdur İl Halk Kütüphanesi, no. 2212/02.

Hacimli bir eserdir (Bayezid nüshası 240 varak). Kâtib Çelebi hatalı olarak bu eserin Türkçe olduğunu söyler. ${ }^{5}$

Müellif ferağ kaydında eserini 955 yılının Ramazan ayında (1548), salı günü tamamladığını kaydeder. Eserin başında konuların bir fihristini verir. Yirmi beş bölümden oluşan eserin bölümlerine göre konuları şunlardır: 1. Hz. Peygamber'e ittiba etmek, Yaratıcı'yı isbat ve O’na iman etmek; 2. Sularla ilgili meseleler; 3. Hamama girmek, gusül, hayız ve nifas; 4. Necasetler ve bunları temizlemek; 5. Teyemmüm, mest üzerine mesh etmek; 6. Kıbleye yönelmek, namazın vakitleri, ezan ve mescid; 7. Abdesti ve namazı bozan şeyler; 8 . İstinca ve abdest; 9. Niyet, setr-i avret, bedeni, elbiseyi ve namaz kılınan mekanı temizlemek; $10 . \mathrm{Na}$ mazın farzları, iftitah tekbiri, namazın keyfiyeti ve namazda kıraat; 11. Namazın

3 Kayhan Atik, Lütfi Paşa ve Tevârih-i Âl-i Osman, Ankara: 2001, s. 16-17.

4 Tevârih-i Âl-i Osman (İstanbul, 1341), s. 3-4.

5 Kâtib Çelebi, Keșü̈z-Zünûn, II, 954. 
vacipleri, vitir namazı, namazın sünnetleri ve nafile namazlar; 12 . Sehiv, tilavet ve şükür secdesi; 13. İmamet, iktida, lâhık, mesbûk; 14. Namazda mekruh olan ve olmayan şeyler, hasta namazı, kaçırılan namazların kazası; 15. Cuma namazı; 16. Yolculuğun hükümleri, hayvan üzerinde ve geminin içinde namaz; 17. Bayram namazları, fıtır sadakası, teşrik tekbirleri, kurban; 18. Korku namazı, güneş ve ay tutulma namazı, istiska namazı, Kabe'nin içinde namaz; 19. Cenaze ahkamı, ölüyü yıkamak, hakkında vasiyet etmek caiz olan ve olmayan kişiler; şehid; 20. Ticaret malının ve hayvanların zekatı, öşür ve nezir; 21. Oruç, itikaf, teravih namazı; 22. Hac, hacda yapılan ameller, ihramın keyfiyeti, ihramlıken yapılmamas1 gereken şeyler; 23. İlmin faziletleri, Ehl-i sünnet ve cemaatin hususiyetleri ve müteferrik meseleler; 24. Kerahiyet ve istihsan (günlük hayatta helal, haram ve mekruh olan şeyler), küfrü gerektiren sözler; 25. Yeminler. ${ }^{6}$

Eser kapsamlı ve mukayeseli bir ilmihal niteliğindedir. Fakat bilhassa 23, 24 ve 25 . bölümlerde devrin güncel tartışmalarına sşık tutabilecek nitelikte meselelere de temas edilir. İbadetlerle ilgili ayrıntılı hükümler dışında kitap emr-i maruf ve nehy-i münker, zındık ve ilgili kavramlar, toplumsal hayatta görülen bazı yanlış davranışlar, sûfilerin bazı uygulamalarının eleştirisi, çalışıp kazanmanın gerekliliği, irade hürriyeti gibi birçok meseleye temas eder. 23. bölümde Ehl-i sünnet'in temel özelliklerinin yanısıra Ehl-i sünnet dışı fırkalar da tek tek zikredildiği için bu bölüm muhtasar bir mezhepler tarihi hüviyetindedir. Müellif her konuyu dört fikıh mezhebi çerçevesinde mukayeseli şekilde incelemiş, hemen her cümlenin kaynağını belirtmiştir. Mukayeseli bir eser olmakla birlikte müellifin Hanefî mezhebine ait kaynak eserleri vukufiyetle kullandığı, bilhassa mezhebin müteahhir dönemine ait nevâzil ve vâkıat kitaplarının belli başlılarını dikkate aldığı görülmektedir.

Lutfi Paşa eserinin helaller ve haramlar bölümünde, Câmiu'l-Fetvâ isimli esere referans yaparak sultanın elini öpmenin caiz olduğu, fakat onun önünde eğilmenin mekruh, yer öpmenin ise -alnı yere koyup secde etmeye nazaran daha hafif olsa da- caiz olmadığını ifade eder. ${ }^{7}$ Böylelikle devlet protokolünde yer almakla birlikte benimsemediği bazı davranışları bu vesileyle eleştirdiği söylenebilir. Yine bilhassa 16. yüzyılda tartışmalı meselelerden tazir bi'l-mal (tazir olarak mâlî/ parasal ceza) ile ilgili olarak, Tâhir b. Ahmed b. Abdürreşid'in Hulâsatül-Fetâvâ adlı eserinden şöyle bir nakil yapar: "Güvenilir (sika) birisinden şöyle işittim:

6 Lutfi Paşa, Zübdetül-Mesâil, Bayezid Devlet Kütüphanesi, no. 1985, vr. 1a-2a.

7 Lutfi Paşa, Zübdetü'l-Mesâil, 202a. 
Kadı veya vali uygun görürse mal ile tazir uygulanabilir. Bu durumlardan birisi de cemaatle namaza devam etmeyen kişidir, ona mal ile tazir uygulanabilir."

Zübdetül-Mesâil'in emr-i maruf ve nehy-i münkerden bahsettiği bir yerinde, Lutfi Paşa’nın vazifesinden ayrılışına ışık tutacak şekilde yorumlanması mümkün bir pasaj bulunmaktadır. Müellif burada hangi durumlarda emr-i maruf yap1lıp hangi durumlarda yapılamayacağını anlatmaktadır. Kişi eğer marufu emredip münkerden nehyetmek amacıyla konuştuğunda sözünün fayda etmeyeceğini, hatta bunun zararlı olacağını bilirse bunu yapması vacib olmadığı gibi kimi durumlarda haram bile olur. Ancak münker işlenen yerlerde bulunmaması, münkeri müşahede etmeyecek şekilde evine çekilmesi gerekir, yalnızca önemli ve elzem işleri için dışarı çıkar. Böyle bir kimsenin bulunduğu beldeden hicret etmesi gerekmez, ancak fesat kendisini kurtulamayacağı şekilde sarmışsa, yahut sultanlara zulüm ve münkerât işleme konusunda yardım etmeye zorlanıyorsa, gücü yettiği takdirde bulunduğu yerden hicret etmesi gerekir. Zira kaçmaya gücü yeten için ikrah bir mazeret değildir. ' Lutfi Paşa’nın Âsafnâme’de görevinden kendi isteğiyle ayrıldığını ifade eden cümleleriyle ${ }^{10}$ buradaki ifadelerini birbiriyle irtibatlı olarak düşünmemiz mümkündür.

8 Lutfi Paşa, Zübdetül-Mesâil, 102b. Müellif aynı eserin bir başka yerinde (189b) de aynı konuya değinir. II. Bayezid'e ithaf ettiği eserinde Muhyiddin Seydî Çelebi de hakkında had şeklinde bir belirleme olmayan cezalarla ilgili olarak devlet başkanının öyle uygun gördüğü takdirde bedenî ceza yerine mâlî ceza takdir edebileceğini söyler. Muhyiddin Seydi Çelebi, Ehâdîs Tetéallak biAhkâmi's-Saltana, Süleymaniye Ktp., Laleli no.639, vr. 60a. Bu pasajdan beni haberdar eden değerli öğrencim Büşra Çetin’e teşekkür ederim. Âşık Çelebi'nin mâlî ceza ile ilgili olarak devrinin âlimlerine nispet ettiği görüş için bkz. Asım Cüneyd Köksal, Fıkıh ve Siyaset (İstanbul, 2016), s. 128-130.

9 Lutfi Paşa, Zübdetül-Mesâil, 211a.

10 "Bu hakîr mansıb-1 vizârete vusûl buldukda ahvâl-i Dîvân-ı Alîşânı hayli muhtell ü perîşân bulmuş idüm. Mümkin olan mertebe yedi yıl mikdârı tedbîr ile nizâm buldurdum. Ba'dehû saâdetlü Pâdişâhımuza ba'zı münâfikîn-i ehl-i garaz kim ellezîne fî kulûbihim maraz nifâk idüp ba’zı husûsla haremimüze müteallik mağlûb-1 nisâ olmayub anların keyd u mekrinden emîn olmağıçün sadr-1 a'zamlıkdan fâriğ olmağı evlâ görmeğin Edirne’ye çiftliğime gidüp kûşe-i inzivâda ferâğ-1 billâh cenâb-1 izzete duâda olmuşdum. Devlet-i dünyâyı fânî bilüp cümleden el çekdüm." (Âsâfnâme (Kütükoğlu neşri), s. 4). Lutfi Paşa’nın azlinin sebebiyle ilgili meşhur rivayetin kaynağı Mustafa Âlı̂dir. Azlin sebebi, Fransảnın Venedik elçisi piskopos Pellicier’ye göre ise Paşa’nın zevcesine kötü muamelesinin yanısıra, Macar seferinden vazgeçirmeye çalıştığ 1 için padişahın hiddetine maruz kalmasıdır (Pál Fodor, "Macaristan’a Yönelik Osmanlı Siyaseti, 1520-1541", çev. Özgür Kolçak, İstanbul Üniversitesi Edebiyat Fakültesi Tarih Dergisi, 40 (2004), s. 54. Ayrıca bu azil hadisesinin o devirde birtakım asılsız dedikodulara sebep olduğu anlaşılmaktadır (mesela bkz. Luigi Bassano, Kanuni Dönemi Osmanl İmparatorluğu’nda 
Zübdetül-Mesâil farklı disiplinlerin bakış açısından ve muhtelif cihetlerden çalışılması gereken önemli bir eser olarak durmaktadır.

\section{Risâletü'l-Künûz fî Letâifi'r-Rumûz fi'l-ehâdîsi'l-erba'în.}

Süleymaniye Kütüphanesi Pertev Paşa bölümü 90 numarada yer alan bir mecmuanın ilk eseri olan el-Künûz, müellif eserin girişindeki ifadesine göre ${ }^{11} 957$ (1550-1551) senesinde kaleme alınmıştır. ${ }^{12} 70$ varaklık eserde müellifin seçtiği kırk hadis şerh edilmektedir. Müellif hadisleri ağırlıklı olarak fikhî cihetten şerh etmiş, füru ve fetva kitaplarını yoğun bir biçimde kullanmıştır. Ayrıca eserindeki hadislerin bir kısmını - diğer eserlerinde de sık sık yer verdiği bir tema olan- Ehl-i sünnet'e uyma hassasiyetini ifade eden hadislerden seçmiştir.

3. Risâle fî Tashîhi'n-Niyye ve'l-Amel bihâ (Hamidiye 197/5) 3 varaklık küçük bir risaledir.

4. Risâle fî Takrîri'l-Ervâh Eyne Tasîrû İâ Ubricû min Hâzibi'l-Ecsâd

5. Risâle fî Takrîri Men Ehabbe Likāe[Allabe / Rabbeb] ve Men Keribehu

6. Risâle fî Takrîri'ş-Şühedâ ve mâ Yete'allak bi-Umûri'l-Abireti

7. Risâle fî Hasâisi Ehli's-Sünneti ve'l-Cemâati ve fî Beyâni Ehli'l-Ehvâi ve'd-Dalâle

8. Risâle fî Tashîhi Salâti'l-Cum'a ve mâ Yete’allak bihâ mine’l-Fedâil ve'l-Âdâb

9. Risâle fî Beyâni Duhûli'l-Hammâm ve mâ Yete'allak bihâ ve'l-İhtidâb ve Taklìmi'l-Ezâfîr

10. Risâle fî Beyâni Metâ Yenkatı'u Ma'rifetü'l-Abdi mine’n-Nâs Inde Hâleti'l-Mevti ve fi't-Tevbeti ve Beyânihâ ve fi't-Tâibi men Hüve

11. Risâle fî Takrîri's-Sayd ve'z-Zebâih ve fî mâ Yabillu ve mâ lâ Yabillu. (Hacı Selim Ağa Kütüphanesi, 652, vr. 134-138.)

Gündelik Hayat (çev. Selma Cangi, İstanbul, 2015), s. 61. (Son iki çalışmadan beni haberdar eden Y. Doç. Dr. Zahit Atçll'a müteşekkirim.) Mustafa Âlînnin "menkuldür ki” diye başlayan anlatısının da bu kabilden olması ihtimal dahilindedir.

11 Risâletü'l-Künûz fì Letâifír-rumûz, Süleymaniye-Pertev Paşa, no 90, vr. 3 b.

12 Ali Bey’in düştüğü dipnota göre, eserin Viyana Kütüphanesi’nde bir nüshası daha bulunmaktadır (s. 4). 


\section{Risâle fî Beyâni’t-Tedâvî ve’l-Mesâyib ve Telkîni'l-Meyyit ve mâ Yüstehabbu min Abvâli'l-Mubtadırîn inde'l-Mevt}

\section{Risâle fî Beyâni Ef'âli'l-İbâd ve Ya'nî bihi el-İhtiyâri'l-Cüz’î}

Lutfi Paşa, kaleme aldığı Türkçe kitapları ise şöyle sıralamaktadır:

14. Tenbîhül-Âkılîn ve Te'kîdü'l-Gâfilîn. ${ }^{13}$ Müellif, Tevârih'de bu eserinin "icmâlî ve mufassalî usûl-i dine müteallik" olduğunu belirtir.

Nüshaları: Millet Kütüphanesi, Ali Emiri, no. 257 (vr. 1-52); Süleymaniye, Kemal Edip Kürkçüoğlu, no. 2 (58 varak); İstanbul Üniversitesi Ktp., TY., 1930.

Müellif eserin dört bölüm olduğunu belirtip bölümlerin muhtevasını şöyle özetler: "Evvelki fasl: Farz olunan ilmin ve fazilet-i ilmin beyanındadır. Ve iman ve islam bilinmez, illâ ilm ile. Ve İkinci Fasıl: İman ve İslam beyanındadır. Üçüncü Fasıl: Tevhîd ve Müteşâbihât beyanındadır. Ve Dördüncü Fasıl: İmanı bilenin ve bilmeyenin hükmü beyanındadır." ${ }^{14}$ Tuhfetü̈t-Tâlibîn'den önce yazdığını bildiğimiz için en geç 951 (1544) yılında tamamlanmış olmalıdır.

Azledildikten kısa bir süre sonra kaleme aldığı eserinde velînimeti Kanunî Sultan Süleyman'ı şöyle anar:

"Bilgil ki bu hakīr-i'15 bî-mikdâr ve nahîf-i günahkâr, Allahu Teâlâ’nın rahmetine muhtâc, ve dahi Muhammed Mustafâ (s.a.v.)'nın şefâatine ümîdvâr olub Lutfi bin Abdülhay (gaferallahu leh) şol âlî dergâhın ${ }^{16}$ kemterîn duâgûlarından ${ }^{17}$ idi ki Sultân-1 âlem, pâdişâh-1 benî Âdem, şehriyâr-1 cihân, zıllullahi 'alâ

13 Tevârib'in 1341 baskısında eserin ismi “Kitâbu Tenbîhi'l-Gâfilîn veyâ Keydi'l-Gâfilîn” şeklinde geçer (s. 4). Dipnotta nâşir, eserin Viyana nüshasının başlı̆̆ının Kitâbu Tenbîhi'l-Gâfilîn ve Te’kîdi'l-Gâfilinn olduğunu yazar. Fuat Köprülü (s. 140) ve Kayhan Atik (s. 16) de eserin ismini bu şekilde, M. Serhan Tayşi ise Tenbîhül-Gâfilîn ve Te’kîdi'l-Kâsilîn (s. 20) şeklinde kaydederler. Ancak hem eserin bize ulaşan iki nüshasının zahriyesinde, hem de müellifin Tuhfetüt-Tâlibîn adlı eserinin girişinde (2a) ve bir başka yerinde (10a) müellifin bu esere yaptığı atıflarda, bu eserin ismi Tenbîhül-Âkılîn ve Te’kîdül-Gâfilîn şeklinde geçtiği için, yukarıdaki diğer bütün isimlendirmeler yanlıştır. Eserin ismini sadece M. Tayyib Gökbilgin -bir nüshasını gördüğü için- doğru kaydetmiştir (Gökbilgin, "Lutfi Paşa”, VII, 100).

14 Lutfi Paşa, Tenbîhül-Âkılîn, vr. 3b-4a. Fuat Köprülü, bu eserin bir nüshasını bir keresinde sahaflarda gördüğünü söyler ve içeriğini aynı ibarelerle aktarır (Köprülü, s. 140).

15 Kürkçüoğlu nüshasında "bende-i”.

16 Kürkçüoğlu nüshasında "dergâh-1 âlînin”.

17 Kürkçüoğlu nüshasında "bendelerinden". 
ehli'l-îmân bâsıtu'l-emni ve'l-eymân, nâşirü'l-'adli ve'l-ihsân, mu'azzü’d-dünyâ ve'd-dîn, gıyâsü'l-İslâmi ve'l-müslimîn, melce'i'd-du'afâi ve'l-mesâkîn, kāmi'u'lküfri ve'l-'inâd, dâfi'u'z-zulmi ve'l-fesâd, hâfizu bilâdillah, nâsıru 'ibâdillah, nâzım-1 umûr-i âlem, ${ }^{18}$ nizâm-1 sebeb-i mülk-i devrân, ve âyet-i rahmet-i Rahmân, mevlâ mülûki'l-Arabi ve'l-Acem, Sultan ibnü’s-sultân, Sultan Süleyman b. Sultan Selim Han -Allah Teâlâ devletin dâim edüb ana her dem yardımcı olsun- hâliyâ bu bî-mikdâr-1 hakīri hâkdan kaldırub liyâkat ve istihkāk[1] yoğiken vizâret mesnedine ulaştırdılar. Hak Teâlâ cemî‘ zamâne hatalarından emîn eylesün, âmin."”9

İki nüsha arasındaki bazı ibare farklılıklarının yanısıra, yukarıdaki pasajda yer alan uzun dua kısmı Kürkçüoğlu nüshasında bulunmamaktadır. Bu durum da, müellifin eserini ileriki yıllarda yeniden gözden geçirmiş ve bazı tasarruflar yapmış olma ihtimalini gündeme getirmektedir.

Tenbîhüll-Âkılîn'in üçüncü bölümü, bir mecmua içerisinde müstakil bir risale olarak da istinsah edilmiştir (Tevhîd-i Müteşâbihât. Süleymaniye Ktp., Halet Efendi, 820, vr. 36-52.)

15. Tuhfetü't-Tâlibîn. Lutfi Paşa bu eserin “imana ve ibâdâta müteallik” olduğunu söyler. Müellif hatlı olması muhtemel bir nüshası Süleymaniye Ktp., Fatih, no. 1507 'de muhafaza edilmektedir. 240 varaktır.

Lutfi Paşa, girişte Tuhfetü't-Tâlibîn'i, Tenbîhül-Âkılîn ve Te’kîdül-Gâfilîn adlı eserini tamamladıktan sonra yazdığını söylemektedir. ${ }^{20}$ Ferağ kaydında ise kitabını 951 (1544) yılı Muharrem'in başında tamamladığını belirtir. ${ }^{21}$

Müellif eserini yazma gerekçesini şöyle anlatıyor:

"Bu hakīr, zelîl, za'îf, Allahu Tebâreke ve Teâlầnın rahmetine muhtacterîn Lutfi bin Abdülmuîn der: Şol vakit ki îmân beyân eder Tenbîhül-Âkılîn ve Te’kîdülGâfilîn adlu kitâbdan ferâgat olundiyse, günlerden bir gün mesâil-i fikha tâlib ve râgıb olan bazı kimesneler dediler ki: 'Nolaydı, ilm-i fikıhdan bir müfîd muhtasar kitâb Türkî-dil üzre cem` olunub yazılaydı ki, ol kitab içinde tâlib olduğumuz mesâil bulmağa âsân olaydı. Ve hem siz dahi sevab ıssı olaydınuz.' diyu

18 Burada "efdalu ve ekmelu ve evlâd-ı benî Âdem" şeklinde bir ibare bulunmaktadır ki hem ifade hem anlam bakımından yanlış görünmektedir.

19 Lutfi Paşa, Tenbîhül-Âkılîn ve Te’kîdüll-Gâfilinn, Millet Kütüphanesi, Ali Emiri, no. 257, vr. 2a-2b.

20 Lutfi Paşa, Tuhfetü't-Tâlibîn, Süleymaniye Ktp., Fatih nr. 1507, vr. 2a.

21 Lutfi Paşa, Tuhfetüt-Tâlibîn, vr. 239b. 
ibrâm etdiler. Bu hakīr dahi anların sözün dutub diledi bir nesne cem‘ ide ki ol tâlibler andan faydalanalar ve kendü dahi sevab issı ola. Ve Allahu Teâlâdan yardım dileyüb bu kitabı te’lîf eylemesine şurû‘ olundu. Ve bir niçe mesâil kütüb-i mu'tebereden ihtiyâr olunub şol ki tâliblerin murâdıydı, Türkî-dil üzre cem‘ olundu." 22

Müellif, eserini Türkçe yazmasının gerekçelerinden biri olarak, Hz. Peygamber'in "İnsanlara anlayışlarına göre konuşun” hadisini gösterir. Ayrıca müftiler fetvalarını, müderrisler derslerini, vâizler vaazlarını Türkçe vermekte, müfessirler tefsirlerini, muhaddisler hadislerini yine bu dil ile ifade etmektedirler. Böyle olunca "her iklîm halkı kendü yerlerin libâsiyle mülebbes olmak münâsibdir."23

Lutfi Paşa, eserine verdiği önemi, Sultan Süleyman'a ithaf etmek suretiyle gösterir:
"Evet, bu kitabı te’lîf idüb cem‘ iden şöyle münasib gördü ki bu kitâb-1 dil-pezîr Sultânü'l-Arab ve’l-Acem nâm-1 şerîfleri ile müzeyyen olub sâir kitablardan im- tiyaz bula ki, ol imâm-1 zamân ve halîfe-i devrân sultânü'l-berreyn ve'l-bahreyn, Ferîdûn-fer, Sikender-der, muğ̂is-i ehlü'l-İslâm ve'l-müslimîn, mu înü’d-dünyâ ve'd-dîn Sultân ibn-i Sultân ibn-i Sultân, Sultân Süleymân Hân bin Selîm Hân bin Bâyezîd Hân'dur. Hak celle ve 'alâ ömrin ve devletin ziyade idüb sâye-i ilâhiyyesin ve sa âdet-i ezeliyyesin tâ inkırâz-1 devr-i zamân ve inkızâ-i müddet-i cihân pâyende ve pâyidâr eylesün, âmin." ${ }^{24}$

Lutfi Paşa, Tuhfetü̈t-Tâlibîn ile Tenbîhül-Âkılîn ve Te’kîdül-Gâfilìn adlı kitapları arasında bir tamamlayıcılık ilişkisi bulunduğunu düşünür. Nitekim bunlardan daha sonra kaleme aldığı Hayât-ı Ebedî adlı eserinde, Tenbîh'in imanı, Tuhfe' nin ise ibadetleri açıklayan eserler olduğunu ifade eder. Muhteva olarak ise Tuhfe' nin Zübdetül-Mesâil ile yakın bir irtibatı vardır. Müellif, Tuhfetü't-Tâlibîn' in muhtevasını eserin girişinde başlıklar halinde özetler. Yirmi beş bölümden oluşan eserin muhtevası büyük ölçüde Zübdetüll-Mesâil ile örtüşmektedir. Zübde'de yer alıp da Tuhfe'de yer almayan başlıklar arasında kerahiyet ve istihsan, elfâz-ı küfr, Ehl-i sünnet ve cemaatin hususiyetleri dikkati çekmektedir. Yukarıda zik-

22 Lutfi Paşa, Tuhfetüt-Tâlibîn, vr. 2a-2b.

23 Lutfi Paşa, Tuhfetüt-Tâlibîn, vr. 3a.

24 Lutfi Paşa, Tuhfetü̈t-Tâlibîn, vr. 2b. 
rettiğimiz gibi Zübde’nin kaleme alınışı, Tuhfe'den dört sene sonradır. Hemen hemen aynı hacimde ve aynı başlıklara sahip olan bu eserlerden Türkçe olanının Arapça'ya müellifi tarafından birebir tercüme edildiğini söyleyemeyiz. İki eserin bazı bölümleri üzerinde yaptığımız karşılaştırmadan edindiğimiz kanaate göre, Tuhfe' nin daha ziyade halkı irşad etme amacı taşımasına karşın, Zübdènin hedef kitlesi Arapça bilen, az çok İslâmî ilimlere âşina kişilerdir. Zübdède daha çok 1stılah kullanılmış, İslâmî ilimlere dair eserlere daha çok atıf yapılmıştır. Dolayısıyla Paşa’nın Tuhfe'de ele aldığı meseleleri Zübde'de daha geliştirerek ve Arapça olarak yeniden telif ettiğini söyleyebiliriz.

16. Hayât-ı Ebedî. Müellif Tevârih'de bu eserin "Ehl-i Sünnet ve'l-cemaate ve ehl-i hevâ ve elfâz-1 küfre müteallik" olduğunu kaydeder. Süleymaniye Ktp., Hacı Mahmud Efendi bölümü no. 1524 (131 sayfa) ${ }^{25}$ ve Millet Kütüphanesi, Ali Emiri, no. 257/2'de (59 varak) birer nüshası bulunmaktadır. Müellif bu eserini 24 Rebiülevvel 953 (25 Mayıs 1546) günü tamamladığını belirtir. ${ }^{26}$

Lutfi Paşa Hayât-ı Ebedînin başında kitabın sebeb-i telifini anlatır ve iki kitabına atıf yapar:

"Bu zelîl ü za'îf ü hakīr el-muhtâc ilâ rahmetillâhi teâlâ Lutfi bin Abdülmuîn eydür ki: günlerden bir gün bazı eshâb-1 vefâ ve ihvân-1 safâ cem'olub ve iltimâs idüb dediler ki: 'Nolaydı, bize Ehl-i sünnet ve cemaat'in hasletlerin, dahi ehl-i hevânın envâ‘-1 fırkaların ayân, dahi elfâz-1 küfri beyân idüb bir muhtasar ve müfîd kitâb cem‘ ideydünüz, tâ ki gereklüsün dutub, dahi bize ve dinimize zarar virüb yaramayandan sakına idük. Nitekim bundan evvel imanı beyan ider Tenbîhüll-Âkulîn ve Te’kîdül-Gâfilîn, dahi ibadâtı 'ayân ider Tuhfetü't-Tâlibîn cem` etdünüz ki müslümanlar faydalandı, dahi faydalanur. Ve dahi Hazret-i Resulullah (s.a.v.) buyurmuşdur ki: 'Nâsın hayırlusı oldur ki nâsa nef i değe, ve nâsın faydasuzı oldur ki nâsa faydası değmeğe.' İmdi sizün hayrunuz nâsa değdi, dahi değsün. Ve şöyle kim bildüğünüzden sonra bu iltimasımızı kabul etmeyüb bize beyan itmeyesiz, faydasız nâsdan olmanuz mukarrerdir. (...)' Bu hakīr dahi hadîs-i mezkûr mûcibince ve bu âyet-i kerîme muktezâsınca ol yârenlerümüzün ve karındaşlarımızun iltimasların cân u dilden kabul idüb elden geldikce makdûrumuzu diriğ itmeyelüm inşâallahu teâlâ diyu cevab virildi. Bu üftâde-i bî-mikdâr dahi nice dürlü selef-i sâlihîn kitabların tetebbu' idüb içlerinde Ehl-i

25 Bu nüshada eserin başında kitabın ismi olarak "Kitâbü'l-İrfân fî Ma'rifeti'l-Fetâvâ ve’l-Edyân" yazilıdır.

26 Lutfi Paşa, Hayât-ı Ebedî, Millet Kütüphanesi, Ali Emiri, no. 257, vr. 105 b. 
sünnet ve cemaat'in hasletlerin ve ehl-i hevânın bid'atlarına ve elfâz-1 küfre müte'allik envâ'-1 mesâil bulundu ki zamanımızda gözler görmüş ve kulaklar işitmiş değül. Pes ol azîz karındaşlarımızun ve muvâfık yârenlerimizün sözlerine binâen Arabîden Türkîye terceme idüb ${ }^{27}$ ol selef-i sâlihîn kitabları sözlerinin envâ‘'ından bir risâle cem' olunub Hayât-ı Ebedî deyu ad verildi. Zira bir kimesne mü’min olub dahi bu risalenün içinde olanların kendüye gereklüsün tutub ki ol iman, dahi Ehl-i sünnet ve cemaat hasletleridür, ve gerekmezinden ictinab eylese kim ol bid'at ehl-i hevâdur, dahi elfâz-1 küfrdür, ol kimesne mü'min olub ebedî hayatda olmuş gibi olur." 28

Müellif eserini yedi bölüme ayırmıştır. Bölümlerin içerikleri kendi ifadeleriyle şu şekildedir:

"Evvel fasl Ehl-i sünnet ve cemaat ve ehl-i hevâ beyanındadır. İkinci fasl Allah Teâlầnın zâtına ve sıfâtına mütéallik ve dahi göklerde ve yerlerde Allah Teâlâ’nın mekânı var diyenlerin, dahi gaybdan haber virenlerin beyanındadır. Üçüncü fasl melâikeye ve kütübe ve enbiyâya âid olan kelimât beyanındadır. Dördüncü fasl imana ve namaza ve zekata ve oruca ve ezkâra ve umûr-i âhirete mütéallik olan kelimât beyanındadır. Beşinci fasl emr-i ma'rûf ve nehy-i münkere ve helale ve harama ve ilme ve ulemaya ve selâtîne ve cebâbireye mütéallik olan kelimât beyanındadır. Altıncı fasl küffâra nisbet etmek, dahi kâfiri müslüman üzerine tercih etmeğe ve küfrü öğredüb telkīn etmek dahi kâfir olmağa emr etmek beyanındadır. Yedinci fasl ehl-i bid'atun tekfîrini icab iden nesneler ve müteferrikât beyanındadır." 29

Zübdetü'l-Mesâilde yer alıp Tuhfe'de bulunmayan içeriğin bir bölümü Hayât-ı Ebedînin muhtevasıyla irtibatlı görünmektedir. Buna göre müellifin, Zübde’yi telif ederken Tuhfénin yanısıra Hayât-ı Ebedı̊deki muhtevayı da dikkate aldığı tahmin edilebilir. Eserin 5. bölümünde zamanın padişahını abartılı ifadelerle övmenin mahzurlarına dikkat çeken Lutfi Paşa, devrin hükümdarı için "mutlaka âdildir" demenin, onun hakkında "şehinşah" gibi ifadeler kullanmanın hükümlerine değinir. ${ }^{30}$

27 "Arabîden Türkîye terceme idüb” ibaresi Ali Emiri nüshasında yoktur.

28 Lutfi Paşa, Hayât-ı Ebedî, Millet Kütüphanesi, Ali Emiri, no. 257, vr. 53b-54b; Süleymaniye

Ktp., Hacı Mahmud Efendi no. 1524, vr. 1-3 (bu nüshada varakların yalnız a yüzüne yazılmıştır).

29 Lutfi Paşa, Hayât-ı Ebedî, Ali Emiri, vr. 54b-55a.

30 Lutfi Paşa, Hayâtıı Ebedî, 94 a. 
17. Risâle-i Suâl ve Cevab. "Eğer sorsalar ki" / "el-Cevab” üslubunda kaleme alınmış çok muhtasar bir akaid-ilmihal risalesidir. Süleymaniye Ktp., Kılıç Ali Paşa no. 378 (vr. 64-73); Hacı Mahmud Efendi, no. 6385 (vr. 1-6); Millet Kütüphanesi, Ali Emiri, no. 257'de (vr. 106-110) birer nüshası bulunmaktadır. Kayhan Atik bu risaleyi -hangi nüshaya dayalı olarak hazırlandığını belirtmeksizin- neşretmiştir ("Lütfi Paşa’nın Risâle-i Sual ve Cevab İsimli Eseri”, Erciyes Dergisi, Kayseri, Ekim 1995, say1 214, s. 6-9).

18. Risâle-i Niyyet. Millet Kütüphanesi, Ali Emiri, no. 257'de bir nüshası bulunmaktadır (vr. 110b-114a).

Lutfi Paşa, Tevârih'de risalenin "bazı mesâil-i mühimme beyanında" olduğunu ifade etmekle yetinir. Müellif ifade etmese de Risâle fî Tashîhi’n-Niyye ve’l-Amel bihâ şeklinde kaydettiği Arapça risalesi ile Risâle-i Niyyet arasında büyük ölçüde bir tercüme ilişkisi olduğu anlaşılmaktadır. Yalnız Arapça metin Türkçe metinden biraz daha uzundur. Yukarıda telif tarihlerini zikrettiğimiz eserlere baktığımız zaman, Paşa'nın Türkçe eserlerini genellikle Arapça eserlerinden daha önce kaleme aldığı, aralarında irtibat bulunan eserlerinde de Arapça olanı daha çok işlediği tespitinde bulunabiliriz. Dolayısıyla Türkçe niyet risalesini önce, Arapça risaleyi daha sonra -ilk metni geliştirerek- kaleme aldığını bir tahmin olarak ileri sürebiliriz. Önemli olan bir başka nokta ise, Risâle-i Niyyet ile, Paşa’nın diğer bir telifi olan Risâletül-Kunûz fî Letâifír-Rumûz arasında da yakın bir alakanın mevcut olmasıdır. Risâletüll-Kunûz'da şerhedilen ikinci hadis niyetle alakalıdır ("Ameller niyetlere göredir.") Niyet risalesiyle bu ikinci hadisin şerhini mukayese ettiğimiz zaman, iki metin arasında da büyük bir örtüşme sözkonusu olduğunu görüyoruz. Şu halde Türkçe risale, Arapça risale, sonrasında bu risalenin de içerisinde yer aldığ 140 hadis şerhi metinlerinin telifi kronolojik olarak birbirini izlemiş olabilir. Lutfi Paşa bu muhtasar risalesinde niyet-eylem ilişkisine dair, ilgili kavramları da analiz eden geniş çaplı bir hukuk felsefesi ameliyesine girişmez, mesela Karâfî̀nin el-Ümniyye fì idrâki’n-niyye'si ile yine onun el-Furûk'u gibi konuyu bu yönlerden inceleyen eserlere de atıf yapmaz, ancak niyetin bilhassa uhrevî yönüne ilişkin, niyet-ibadet alâkasına dair derli toplu bir çerçeve çizer.

19. Umûrü'l-Mühimmât. Müellifin ifadesinden bu eserin tıpla ilgili olduğunu öğreniyoruz. ${ }^{31}$

31 Sadettin Özçelik tarafından neşr edilen Kitâbüll-Mühimmât isimli anonim tıp kitabının (Ankara, 2001), Lutfi Paşa’nın mezkur eseriyle alakalı olup olmadığı üzerinde durulmaya değer. Sadettin Özçelik eserin Diyarbakır nüshasının 926 tarihinde istinsah edilmesinden, ayrıca dil ve 
20. Tevârîh-i Âl-i Osman. Başlangııından 1553 yılına kadarki Osmanlı tarihini anlatan bir eserdir. Hâfızıkütüb Âlî Bey tarafından notlu ve açıklamalı neşri yapılmıştır (1341). M. Serhan Tayşi'nin girişi ve indeks ilavesiyle bu neşrin tıpkıbasımı yapılmış (1990), Kayhan Atik tarafından yeni harflerle neşredilmiştir (2001). ${ }^{32}$ Tevarib'in, bilhassa müellifin tercüme-i haline dair olan mukaddime kısmıyla, kendi "meşhûdât ve mesmûâtına" dayalı olayların anlatıldığı bölümlerinin önemli ve ilk elden kaynak niteliğini haiz olduğuna dikkat çekilmektedir. ${ }^{33}$ Eserin biri Viyana Milli Kütüphanesi’nde, üçü Türkiye'de olmak üzere dört nüshası bulunmaktadır. ${ }^{34}$

Lutfi Paşa’nın Tevârîh-i Âl-i Osman'ın girişinde ortaya koyduğu tecdîd anlayışı dikkate değer bir mahiyet arz eder, zira müellifin müceddidler listesi tamamen hükümdarlardan oluşmaktadır. Her yüzyılın başında İslâm'ı yenileyen bir kişinin geleceğini tebşir eden hadisi nakleden Lutfi Paşa, Resûl-i Ekrem'den sonra 2. yüzyılın başında dini yenileyen kişinin Ömer b. Abdülaziz (ö. 101/720) olduğunu yazar. 3. yüzyılın müceddidi Harun Reşid'in oğlu Mu'tasım Billah'dır (ö. 227/842). Mu’tasım'ın kardeşi Emin, Mutezile mezhebini benimsemeleri için halkı zorlayıp ulemaya eziyet etmiş, Mưtasım ise kardeşinin bidatlarını ortadan kaldırmıştı. 4. yüzyılın müceddidi olan Abbâsî halifesi Kâdir Billah (ö. 422/1031), Fâtımîlerin İslâm coğrafyasındaki beyleri kendi mezheplerine çekmeleri karşısında büyük gayret gösterip bu beyleri tekrar Ehl-i sünnet'e kazanmıştı. 5. yüzyılın müceddidi, mülhidlere karşı dikkate değer bir mücadele yürüten Muhammed (Tapar) b. Melikşah'tır (ö. 511/1118). 6. yüzyılın müceddidi, atalarının dinini terk edip İslâm’ı seçen ve müslümanlar üzerindeki ağır vergileri kaldıran ilk İlhanlı hükümdarı Gazan Han'dır (ö. 703/1304). 7. yüzyılın müceddidi, Moğolların hakimiyetine son veren Osman Gazidir (ö. 724/1324). 8. asrın yenileyicisi Çelebi Mehmed (ö. 824/1421), 9. asrı tecdid eden ise Yavuz Sultan Selim'dir (ö. 926/1520). ${ }^{35}$

yazı karakterinden eserin 15. yüzyıla ait olduğu kaaatine varmıştır (Sadettin Özçelik, KitâbüllMühimmât, s. 9). Ancak önsözde (s. ix), muhtemelen sehven, aynı nüshanın 962 istinsah tarihli olduğu ifade edilmektedir. 926 tarihi eserin Paşa’ya nispetini zorlaştırırsa da imkansız kılmayacağı için, bu nazarla eserin incelenmesinde fayda vardır.

32 Atik' in neşri hakkında bir değerlendirme yazısı için bkz. Hayati Develi, "Lütfi Paşa ve Tevârih-i Âl-i Osman' Üzerine”, İlmi Araşttrmalar 14, İstanbul 2002, s. 247-254.

33 Köprülü, "Lutfi Paşa", s. 145; İpşirli, "Lutfi Paşa", DİA, XXVII, 235.

34 İpşirli, "Lutfi Paşa”, DİA, XXVII, 235.

35 Lutfi Paşa, Tevârîh-i Âl-i Osman, s. 7-11. 
Gazan Han’ın yaşadığı zaman itibariyle 6. değil 7. asır için daha uygun olması, Muhammed Tapar ile Gazan Han arasında yaklaşık iki asır, Gazan Han ile Osman Gazi'nin vefatları arasında ise 20 senelik bir zaman bulunması gibi kronolojik sorunlar bir tarafa, Lutfi Paşa’nın müceddid anlayışı başlı başına ilgi çekicidir. Bu listede hiç bir sivil âlimin yer almamasından anlaşıldığına göre onun nazarında dini temsil ve ihya bakımından hükümdarlar âlimlerden önce gelmektedir. Tevârîh ile yakın zamanlarda tamamladığı Halâsül-Ümmède, Kanuni Sultan Süleyman'ın zamanın imamı ve halifesi olduğunu anlattığı bir bağlamda tecdidle ilgili şöyle yazar:

"Bilesin ki Allah’ın her yüzyıl başında göndereceği kişinin mutlaka âlim olması gerekmez. Aksine bazen bir âlim olur, bazen bir halife olur, bazen topluma öncülük eden bir kişi, bazen de itaat edilen bir melik olur. Aynı anda bir halife, melik ve emir birlikte de olabilir. Hz. Peygamber, bunun için bir âlim veya başka birini belirlemiş değildir. Bu kişi, insanların saygı duydukları, kendisine başvurdukları, yasakladığında geri durdukları, emrettiğinde hemen yaptıkları sözü makbul herhangi bir kişi de olabilir."36

Lutfi Paşa’nın Tevârib'te isimlerini zikretmediği dört eseri daha bulunmaktadir:

\section{Halâsï'l-Ümme fî Ma'rifeti'l-E'imme.}

Müellif bu risaleyi 13 Ramazan 961 (12 Ağustos 1554) tarihinde tamamladığını söyler.

Fuat Köprülü, Lutfi Paşa’nın, daha sonra kaleme alacağı için Tevârih'de ismini zikretmediği yalnız bir eserinin bulunduğunu, bunun da Âsafnâme olduğunu ifade eder. ${ }^{37}$ Halâsüll-Ümme ile ilgili ise şu kaydı düşer: "Bursalı Tahir Bey, bu âsâr listesine -hiçbir menba zikr etmeksizin- Paşa’nın Hulâsâtüll-Ümme fî Ma'rifeti’lEimme unvânıyla eimme-i müctehidînin ahvâl ve ictihâdâtından bâhis bir eseri olduğunu da ilave ediyor." ${ }^{38}$ Bursalı eserin ismini ve muhtevasını kaydederken

36 Lutfi Paşa, Halâsüll-Ümme fì Mảrifeti'l-E’imme, Süleymaniye Kütüphanesi, Ayasofya, 2877, 21b-22a.

37 Köprülü, s. 139.

38 Köprülü, s. 142; Tahir Bey, Osmanlı Müellifleri, III, 133. 
hata etmiş olmakla birlikte, bu eser aralarında müellif nüshası da bulunan çeşitli nüshalarıyla günümüze ulaşmıştır.

Halâsüll-ümme risalesi Mâcide Mahlûf tarafından yayımlanmıştır (Dâru'lÂfâki'l-Arabiyye, Kahire, 2001, 76 s.). Risalenin müellif nüshası Süleymaniye Kütüphanesi Ayasofya 2877 numarada kayıtlıdır. Aynı bölümde 2876 numarada kayıtlı bulunan nüsha eserin Farsça tercümesidir. Ayrıca eserin Arapça aslının Topkapı Sarayı Müzesi (Revan Köşkü, nr. 644) ve Yenicami (nr. 1182) kütüphanelerinde birer nüshası daha bulunmaktadır. ${ }^{39}$

Lutfi Paşa’nın Arapça kaleme aldığı bu risalesi hilâfet konusuna tahsis edilmiştir. Risalenin amacı Osmanlı hanedanına mensup padişahların hem sultan hem halife olduklarını ve artık imametin Kureyşîliği şartının geçersiz olduğunu savunmaktır. Halâsüll-Ümme imametin (devlet başkanlığının) şartları ve imamın vazifeleri gibi İslâm kamu hukukuna ait bazı meseleleri çeşitli kaynaklardan ve belirli bir sistematiğe tâbi olmaksızın aktarır.

Müellif risaleyi telif amacını, Abbasi halifelerinden kendi zamanına kadar ümmetin durumunun ne olduğunu ve daha sonrasında ne olacağını sorgulamak, ayrıca Kureyş soyundan gelmeyen bir sultana "imam” ve "halife" unvanlarının verilip verilmeyeceğini ortaya koymak olarak tespit eder ve bu hususu kendisine soran bazı seçkin insanların risalenin yazılmasına vesile olduğunu kaydeder. ${ }^{40} \mathrm{Bu}$ kişiler, Necmeddin Ömer Nesefî (ö. 537/1142) ve Teftâzânî̀nin (ö. 792/1390) imameti Kureyşî olma şartına bağlayan ifadelerine atıf yapmakta, Abbasi halifelerinden sonra söz birliği veya galebe çalmak yollarıyla idareyi üstlenen sultanlara “imam" ve "halife" denilip denilemeyeceğini merak etmektedirler. Nesefînnin dediği doğru olduğu takdirde halifesiz kalmış demek olan ümmetin durumu bilhassa önem kazanmaktadır. Bu soruyu cevaplamak üzere risalesini kaleme aldığını bildiren Lutfi Paşa, araştırması esnasında kullandığı kaynakları da sıralamaktadır ki bu kitapların çoğunluğunun Hanefî füru ve fetva kitaplarından oluştuğu görülmektedir.

$39 \mathrm{Bu}$ risale hakkındaki çalışmalardan görebildiklerimiz şunlardır: Hulusi Yavuz, "Sadrıazam Lutfi Paşa ve Osmanlı Hılafeti”, MÜIF Dergisi, sy. 5-6, 1987-1988, s. 27-54; Muharem Jahja, Lutfi Paşänın Halasu'l-ümmeti fi marifeti'l-eimmeti risalesinin tahkik, tahlil ve tercümesi, Marmara Üniversitesi Sosyal Bilimler Enstitüsü, 2003 (Yayımlanmamış yüksek lisans tezi). Ayrıca yukarıda zikredilen baskıyı neşre hazırlayan Mâcide Mahlûf tarafından yazılan takdim bölümünü (s. 5-34) de zikretmek gerekir.

40 Lutfi Paşa, Halâsüll-ümme, Süleymaniye Kütüphanesi, nr. 2877, 2b. 
Nesefî Akâidìnde geçen "İmam, Kureyşs soyundan olur, Kureyş'ten olmayan kimsenin imam olması caiz değildir” hükmünü eleştirir. Kureyş soyuna mensup olmak bir tarafa, devlet başkanının Müslüman olmasının dahi şart olmadığı şeklinde bir iddiada bulunan müellif şöyle der:

\begin{abstract}
"Âlimlerimiz, 'Kişi, iki şeyle sultan olur: Birincisi kendisine biat edilmek, ikincisi ise hükmünü uygulamak' demişlerdir. Bundan dolayı yukarıda zikri geçen eserlerin müelliflerinden hiçbiri, sultanın ne Kureyş soyundan, ne Haşimî kabilesinden olması ne de Abbasî soyu ya da başka bir soy tarafından izin verilmiş olması gerektiğine dair bir şarta yer vermişlerdir. Yönetimin başına geçen sultanın Müslüman olması dahi şart değildir. Gayrimüslimlerin yönetimi altındaki, halkı Müslüman olan bölgeler, hiç kuşkusuz harp ülkesi değil, Müslüman ülkesidir. İmametin ve emaretin geçerliliği (sıhhati) için adalet de şart değildir. Peki öyleyse Ömer Nesefî, imamın Kureyş soyundan olmasını neye dayanarak şart koşmuş ve hiçbir yoruma imkan tanımayan kesin bir dille 'İmamın başka soydan olması caiz olmaz' diyebilmiştir? Hâlbuki âlimler, imamet(in geçerliliği) için devlet başkanı olacak şahsa biat edilmesini ve kendisinin yönetimi elinde tutup hükmünü yürütecek kudret sahibi olmasını yeterli görmüşlerdir. Durum söylediğimiz gibi olunca ümmetin ve sultanların vaziyeti şer'î kanunlara uygun olmuş olur ve Ömer Nesefînin ifadesinin doğru olmadığı ortaya çıkar.”^11
\end{abstract}

Devlet başkanının Müslüman olmasının şart görülmeyişi, bir taraftan ahkâm-1 sultâniyye geleneğinden radikal bir kopuşu temsil etmekte ise de, diğer taraftan da İslâmî yönetimin kişilerden ve şahsî özelliklerden bağımsızlaşma temayülü gösterdiği, ilkelerin ve yasaların hâkimiyetinde (nomokratik) bir hukukun üstünlüğü anlayışının hâkimiyetine girdiği bir devri sembolize etmektedir.

Lutfi Paşa, kendisinden önce Kureyşîlik şartının kalkmış olduğunu ileri süren Sadrüşşeria (ö. 747/1346) ve Tarsusînin (ö. 758/1357) yanısıra, bu şartın asabiyet temelinde zamana göre değişken olduğunu savunan İbn Haldun'a da atıf yapmamakta, bu durum da bu eserleri görmediğini akla getirmektedir. Müellif risalesinin sonunda zamanın padişahı olan Kanunî Sultan Süleyman'ın “'zamanın imamı” olduğunu, Müslümanların yaşadığı bölgelerin büyük kısmını hükmü altında bulunduran bir sultan olarak kendisine tâbi olunmaya lâyı bir halife olduğunu belirtmektedir. ${ }^{42}$

41 Lutfi Paşa, Halasu'l-ümme, 5b-6a.

42 Lutfi Paşảnın Halâsüll-ümme adlı eserinin muhtevasına dair buraya kadar yaptığım açıklamalar, daha önce neşrettiğim Fıkıh ve Siyaset adlı eserin ilgili bölümünden (s. 149-157) özetlenerek aktarılmıştır. Eserin daha geniş bir tahlili için buraya bakılabilir. 
Lutfi Paşa, Halâsu'l-Ümme'den altı sene önce kaleme aldığı Zübdetü̉lMesâilde halifenin Kureyşî olmasını bir şart olarak zikretmektedir. ${ }^{43}$ Bu konudaki düşüncesinin, 955-961 yılları arasında değişmiş olduğu anlaşılmaktadır. Ancak aynı eserde, Zâhidîyi kaynak vererek bir mesele aktarır. Bir gayrimüslim hükümdar müslüman bir kişiyi bir beldeye vali olarak tayin ederse, bu valinin cuma ve bayram namazlarını kıldırıp kıldıramayacağı sorulmuş, Zâhidî "kıldırabilir" cevabını vermiştir. ${ }^{44}$ Lutfi Paşa 957 (1550-1551) yılında, yani Halâsül'Ümmèden dört sene önce kaleme aldığı Risâletü̈l-Künûz adlı eserinde de, elMültekata isimli esere dayanarak, kadılık görevini kabul etmek için sultanın müslüman olmasının şart olmadığını, gayrimüslimlerin yönetimi altında müslümanların yaşadığı beldelerin harb beldeleri değil, İslam beldeleri olduğunu söyler. ${ }^{45}$ Burada ifade ettiği kazâ fonksiyonu açısından sultanın İslamının şart olmadığı görüşünü, Halâsü̉l-Ümméde kazâ bağlamından soyutlayıp genelleştirerek, hilâfetin kureyşîliği bir tarafa, sultanın müslüman olmasının dahi şart olmadığı görüşüne ulaşmış olmalıdır.

22. Risâle fì Beyâni Asli'l-1̂mân. (Beyazıt Devlet Kütüphanesi, Veliyyüddin efendi, nr. 3242, vr. 4-9). Secîli ve edebî bir mukaddimeye sahip bu Arapça risalede müellif imanın aslı, cevheri ve vasıflarını anlatmayı hedeflediğini söyler. Risalede imanın on sekiz çeşidini ve imanla ilgili meseleleri anlatır.

23. Risâle-i Firak-ı Dâlle. (Süleymaniye, Ayasofya, 2195, vr. 110-123). Bu Türkçe risale, "Ümmetim yetmiş üç firkaya ayrılacaktır..." hadisini şerh eder. Ehl-i sünnetin özellikleri açıklandıktan sonra yetmiş iki bâtıl firka risalede tek tek açıklanır. Risale, Hayât-ı Ebedìnin birinci bölümünün bir özeti gibidir. Ayrıca Zübdetül-Mesâilin 23. bölümü ile bu risalenin muhtevası arasında yakın bir irtibat vardır.

\section{4. Âsafnâme.}

Lutfi Paşąnın en çok bilinen, en çok istinsah edilen eseridir. İlk olarak 1910 yilında Leipzig'de Rudolf Tschudi tarafindan doktora tezi olarak edisyon kritik şeklinde yayımlanmıştır. Hemen bunun akabinde 1326 (1910-11) yılında Ali Emîrî Efendi'nin önsözüyle birlikte İstanbul'da tekrar neşredilmiştir. Daha sonra Ahmet Uğur, Tschudi ve Ali Emîrî neşirlerinin edisyon kritiğini yaparak yeni bir

43 Lutfi Paşa, Zübdetül-Mesàil, vr. 190a.

44 Lutfi Paşa, Zübdetül-Mesâil, vr. 119a.

45 Lutfi Paşa, Risâletül'-Künûz fî Letâifír-Rumûz, vr. 28b. 
neşir gerçekleştirmiş, ${ }^{46}$ Mübahat Kütükoğlu ise eserin yazmalarını yeniden incelemeye tâbi tutarak öncekilerden daha sağlam bir metin tesis etmiştir. ${ }^{47}$ Kütükoğlu bu neşrinde eserin yirmiden fazla yazmasına atıf yapmaktadır. Yaptığımız incelemelere göre eserin başka nüshalarının da bulunduğu anlaşılmaktadır.

Risaleyi dört bab olarak tertip eden müellif, bu bölümleri şöyle ifade eder: "Bâb-1 evvel; etvâr u ahlâk-1 vezîriazam ne resm olmak gerekdür? Padişah ile nece muamele gerekdür, ve reâyâ ahvâliyle nice takayyüd lâzımdır? Anı bildirür. Bâb-1 sânî, tedbîr-i sefer beyanındadır. Bâb-ı sâlis, tedbîr-i hazine beyanındadır. Bâb-ı râbi', tedbîr-i re'âyâ beyanındadır.” 48

Asafnâme daha sonra kaleme alınan birçok siyasetnameye kaynaklık eden bir eserdir. Lutfi Paşa’nın devlet görevindeki tecrübelerini ve tavsiyelerini samimi bir üslupla ortaya koyması itibarıyla çok alaka görmüştür. Müellif Tevârih'te de söz ettiği ulak zulmüne bu risalede de kısaca değinir, Osmanlı memleketinde ulak gibi bir zulüm olmadığını ifade ettikten sonra kendi sadrazamlığı döneminde fukarayı bu külfetten kurtarmak için bazı köşelerde menzil beygirleri vaz ettirdiğini belirtir. ${ }^{49}$ Devletin haksız kazançlardan sakınması gerektiğini, padişahın halkın mallarına haksız yere el koymasının devletin zevaline alamet olduğunu söylediği bir yerde, terekelerin varisi çıkıncaya kadar bekletilmesi gerektiğini, Yavuz Sultan Selim zamanında böyle terekelerin yedi yıl saklandıktan sonra varisi çıkmadığı takdirde hazineye intikal ettirildiğini söyler. ${ }^{50}$ Hizmeti geçen devlet adamlarının mal varlıklarını sebepsiz yere müsadere ettirmemek, hafif bir kabahat sebebiyle onları azl ve idam ettirmemek gerektiğini söyler. ${ }^{51}$ Hazinenin selameti için asker sayısını artırmamak gerektiğini, 12 bin ulufeli yeniçerinin yeterince çok olduğunu ifade eder. ${ }^{52}$ Eserin çeşitli yerlerinde kadim toplumsal statü anlayışının muhafazasının önemine dikkat çeker, reâyânın yönetici sınıfına karışmaması gerektiğini vurgular. Kanuni devrinde kaleme aldığı eserde, bir önceki padişah hakkında

46 "Asafname-i Vezir Lutfi Paşa”; İslam İlimleri Enstitüsü Dergisi, IV, Ankara, 1980, s. 243-258.

Daha sonra bu neşir kitap olarak Kültür Bakanlığı tarafından tekrar yayımlanmışırı (1982).

47 Lutfi Paşa Âsâfnâmesi: Yeni Bir Metin Tesisi Denemesi, İstanbul: İstanbul Üniversitesi Edebiyat

Fakültesi, 1991. Eserin yazma nüshaları için bu çalışmanın girişinde bilgi bulunmaktadır.

48 Lutfi Paşa, Âsafnâme, Süleymaniye Ktp., Laleli, no. 3737, vr. $147 \mathrm{~b}$.

49 Lutfi Paşa, Âsafnàme (Kütükoğlu neşri), s. 9-10.

50 Lutfi Paşa, Âsafnâme (Kütükoğlu neşri), s. 10-11.

51 Lutfi Paşa, Âsafnâme (Kütükoğlu neşri), s. 12, 23.

52 Lutfi Paşa, Asafnâme (Kütükoğlu neşri), s. 35. Bu sayılan hususların Osmanlı siyasî ve iktisâdî tarihi açısından önemine dikkatimi çeken değerli hocam Prof. Dr. Erol Özvar’a müteşekkirim. 
"Sultan Selîm Han merhum selâtînin akl ü izân ve adl ü ihsân ile ekremidür"53 ifadesini kullanması, müellifin samimiyetinin bir göstergesidir.

Eserin Arapçasını 1911 yılında Beyrut'ta Luvis Şeyho neşretmiştir. Hazırlayanın girişte verdiği bilgilere göre esere kaynaklık eden nüsha, Ahmed Vehbi isimli bir edîbin terekesinden çıkmıştır. Eserin başlı̆̆1 "Kânûn-1 Benî Osman" olan bu nüsha iki eserden oluşmaktadır. İlk eser Müezzinzâde Ayn Ali'nin Kavânîn-i Âl-i Osman Der Hulâsa-i Mezâmîn-i Defter-i Dîvân adlı eseridir. İkinci eser ise Lutfi Paşa’nın Âsafnâme’sinin Arapça bir tercümesidir. Luvis Şeyho, tercümenin dilinin basit, halk (ammî) diline yakın, Türkçe ifadelerle dolu bir Arapça olduğunu, parantez içinde bazı hataları düzeltmek dışında eserin diline dokunmadığını belirtir. ${ }^{54}$ Metnin ana başlığ 1 da "Kânun-1 Lutfi Paşa" şeklindedir. Eserin son cümlesinde de "Fehâzâ kanunu’l-müluk es-salife" (Bu, geçmiş hükümdarların kanunudur) ibaresi geçer. Bu neşrin başındaki ve sonundaki "kanun" kelimesinin anlam ve bağlamını, kaynaklarda Paşa’ya izafe edilen "Kanunname” metniyle ilgili bir sonraki başlıkta ele alacağız. Bunun dışında -daha önce herhangi bir tetkike konu edildiğini görmediğimiz- bu neşir bize Âsâfnâme’nin bizzat müellifi tarafından Arapça’ya çevrilmiş olup olmadığı sorusunu sordurmaktadır.

\section{Lutfi Paşa'ya Nispet Edilen "Kanunname”}

Keş̧ü̈z-Zunûn'da Âsafnâme’den bahsetmeyen Kâtib Çelebi, Kânunnâme-i Osmânî isimli bir eserin Türkçe olup meşhur görüşe göre Lutfi Paşaya ait olduğunu yazar. Bu noktadan sonra Keş̧ü'z-Zunûn'un iki baskısı arasında anlama etki eden bir ibare farklılığı vardır. 1310 baskısında ifade şöyledir: "Müezzinzâde, Türkçe risale üzerine Ahmed Han'ın veziri Murad Paşa’nın işaretiyle bir zeyl kaleme aldı (cem etti) ve onu yedi fasıl ve hatime şeklinde tertip etti." ${ }^{5} 1941$ tarihli Yaltkaya-Bilge neşrinde ise ibare şöyledir: "Müezzinzâde Ayn Ali, Ahmed Han'ın veziri Murad Paşa'nın emriyle Türkçe bir risale cem ve onu yedi fasıl bir hatime şeklinde tertip etti." ${ }^{56} \mathrm{Bu}$ ikinci ibare Müezzinzâde'nin kimliğini açık bir şekilde ortaya koymakla birlikte, bu müellifin yazdığı eserle Lutfi Paşa’nın "kanunname" si arasındaki illiyet rabıtası, ilk ibareye nispeten oldukça zayıfla-

53 Lutfi Paşa, Âsafnàme (Kütükoğlu neşri), s. 31.

54 Lutfi Paşa, Kânûn-ı Benî Osman el-Mảrûf bi-Âsâfnâme, nşr. Luvis Şeyho, Beyrut, MatbaatülKatolikiyye, 1911, s. 3-4.

(II, 218)

56 Kâtib Çelebi, Keşǚz-Zunûn, II, 1314. 
maktadır. Osmanzâde Ahmed Tâib (ö. 1724), Lutfi Paşa'nın başka hiçbir eserine atıf yapmaksızın "kānûn-ı Osmâniyyeye müte'allik te'lîfatı" olduğunu yazar. ${ }^{57}$ Tayyarzâde Ahmed Atâ (ö. 1880 ?) da aynı şekilde Paşa’nın bilinen diğer herhangi bir eserine atıf yapmaksızın "kānûn-ı Osmânîye dâir te'lîfâtı görülmemiş ise de mervî ve mesmû'dur" der. ${ }^{58}$ Bursalı Tâhir Bey, Lutfi Paşa’nın eserlerine ait listede buna da işaret eder ve Kâtib Çelebi'nin sözünü ettiği Müezzinzade’nin bu kanunnameyi tezyîl ve tavzîh ettiğini belirtir. Ayrıca hicrî onuncu asır maliyecilerinden Ayn Ali Efendi'nin de mâlî ve idârî kanunlara dair Kavânîn-i Âl-i Osman Der [Hulâsa-i] Mezâmîn-i Defter-i Dîvân isimli 1018 yılında telif edilmiş bir eseri bulunduğunu ve bu eserin Kâtib Çelebi'nin Düstûru'l-Amel adlı eseriyle birlikte basıldığını ifade eder. ${ }^{59}$ Tâhir Bey’in "Müezzinzade" ve "Ayn Ali” olmak üzere iki farklı şahsiyet söz konusu imiş gibi bir üslup kullanmak suretiyle Kâtib Çelebi’nin Lutfi Paşa'nın eserini cem ve tertip ettiğini söylediği şahsiyetin Ayn Ali'den farklı olarak Müezzinzade olduğunu ifade etmesi, Keşfǘz-Zunûn'un 1274 tarihli Bulak veya 1310 tarihli İstanbul baskısını kullanmış olmasından kaynaklanmaktadır. ${ }^{60}$ Fuat Köprülü de 1925 tarihli makalesinde, "Kâtib Çelebi, Paşa’nın bir de 'kanunname'si olup Sultan Ahmed devrindeki Murad Paşa'nın emriyle Müezzinzâde tarafından cem ve tezyîl edildiğini yazıyorsa da..."61 demekte ve eserin Bulak ve Flügel baskılarına atıf yapmaktadır.

Keş̧üz-Zunûn'un müellif nüshasının da kullanıldığı 1941 tarihli baskıdaki ibareye göre, (Veziriazam Kuyucu) Murad Paşa’nın emriyle yazıldığı ifade edilen eser, Müezzinzâde Ayn Ali Efendi'nin Kavânîn-i Âl-i Osman Der Hulâsa-i Mezâmîn-i Defter-i Dîvân adlı kitabıdır. Devlette hazine kâtipliği ve defter-i hâkânî eminliği görevlerinde bulunan ve 17. asrın başlarında vefat ettiği tahmin edilen Ayn Ali Efendi, 1018 / 1609 yılında yazdığı mezkur eserinin girişinde, eserini Sultan Ahmed'e gönderilmesi ümidiyle Murad Paşa'ya ihdâ ettiğini söyler. ${ }^{62}$ Kâtib Çelebi'nin tasvir ettiği gibi yedi fasıl ve hatimeden oluşan mezkur eser, Çelebi'ni Düstûru'l-Ameli ile birlikte 1280 / 1863 yılında basılmıştır. ${ }^{63}$ Fuat Köp-

57 Osmanzade Ahmed Tâib, Hadîkatül'-Vüzerâ (İstanbul, 1271), s. 27.

58 Tayyarzâde Ahmed Atâ, Tarih-i Atâ (İstanbul, 1293), II, 19.

59 Tahir Bey, Osmanlı Müellifleri, III, 133.

60 Kâtib Çelebi, Kesfüz-Zunûn (Dersaadet, 1310), I, 218. Mehmed Tahir Bey 1925 yllında vefat etmiş, Yaltkaya ve Bilge'nin neşri ilk olarak 1941'de basılmıştır.

61 Köprülü, s. 141.

62 Ayn Ali Efendi, Kavânîn-i Âl-i Osman, s. 4.

63 İstanbul, Tasvîr-i Efkâr Gazetehanesi. 
rülü ayrıca Hadîkatül-Vüzerầda Paşa’nın Osmanlı kanunlarına dair telifatı bulunduğunun kaydedildiğini, Evliya Çelebi'nin de on birinci asırda Bitlis hanının iğtinam edilen kitaplarından bahs ederken "Kânunnâme-i Latîfî Paşa” diye bir eseri zikrettiğini, bunun Lutfi Paşa olması gerektiğini söyler. ${ }^{64}$ Fakat Köprülü’ye göre, Paşa tarafından kendi eserleri arasında zikredilmeyen bu kanunnameye bu listede yer verilmesi doğru olmadığı gibi, her icraatını titizlikle kaydeden Paşa’nın böyle bir kanunnameye hiç atıf yapmamış olması, Kâtib Çelebi’nin verdiği bu bilgiyi biraz şüpheli kılmaktadır. ${ }^{65}$ Lutfi Paşa'nın hazırladığ ${ }_{1}$ bir kanunname varsa, böyle bir esere kendi eserleri listesinde yer vermemesini, kanunnameyi hususi bir telif saymamış, bunu yazmayı bir devlet görevi olarak görmüş olması şeklinde açıklamak mümkünse de, Tevârih'de bir icraat olarak bile zikretmemiş olmasını açıklamak kolay değildir. Böyle bir durum, ancak emeklilik hayatında ve Tevârih'i kaleme aldıktan sonraki yıllarda, görev icabı değil de tamamen ilmî bir çaba ile bir kanunname derlemesi yapmış olması halinde açıklanabilir hale gelir. Şu halde bir yandan Kâtib Çelebi, Evliya Çelebi ile Osmanzade Tâib’in ifadelerini, diğer yandan Paşa'dan bize bu minvalde bir eser ulaşmamış olması durumunu açıklayabilmemiz gerekmektedir. Bu hususta biri 17., diğeri 18. yüzyıla ait iki siyasetname yolumuzu aydınlatacaktır.

Sözkonusu eserlerden ilki 17. yüzyılda yaşamış bir müellife, Abdüssamed Abîdîye aittir. Müellif Hazâinül-Kânun isimli eserini Sultan İbrahim'in tahta çıktığı 1049 (1640) yılında yazmış, eseri sultana takdim etmiştir. ${ }^{66}$ Kaynaklarda hakkında bilgi bulamadığımız Abîdî, muhtemelen devşirme asıllı bir katip olarak sarayda yetişmiştir. İstanbul'dan Hicaz'a, Mısır ve Şam'a gittiğini, sınır boylarında vazife gördüğünü, katiplik yaptığını, uzun zaman buralarda vakit geçirdikten sonra vatan arzusuyla yollara düşüp Tuna boylarına, Erdel'e kadar geldiğini anlatır ("Erdel'in intihâ-i serhaddi / Tuna'nın hem kilidi hem seddi") Memleketinin Erdel civarında (Bugünkü Romanya’nın Transilvanya bölgesi) Tuna boyunda, bugünkü Romanya ile Sırbistan sınırına yakın bir bölgede olduğu anlaşılan Abîdî, buralarda bir süre kaldıktan sonra İstanbul'a döndüğünü belirtir. Bu gelişinden önce bu şehirde nice üstadlara hizmet ettiğini, imkanı nispetinde bilgisini artırmaya çalıştığını, tahsil-i ilm ettiğini, Sultan İbrahim tahta geçtiğinde de kendisine takdim edilmek üzere bu eserini nazmettiğini ifade eder. ${ }^{67}$

64 Köprülü, s. 141; Evliya Çelebi, Seyahatname (İstanbul, 1314), IV, 245.

65 Köprülü, s. 141.

66 "Hazret-i pâdişâh-1 rûy-i cihân / Hân İbrahim bin Ahmed Hân" (4a).

67 Abdüssamed Abîdî, Hazâinü̈l-Kânun, Süleymaniye Ktp., Lala İsmail 412, 5b-6b. 
Abîdî, "Kânun-ı Hân Süleymân"1 derleyip bir araya getiren Lutfi Paşànın eseri üzerinde çalışıp bunu nazmen yeniden kaleme aldığını söyler. ${ }^{68}$ Tıpkı Âsafnâme gibi dört bölümden oluşan Hazâinü'l-Kânun bölümlerin muhtevası bakımından da Lutfi Paşa’nın eserini takip eder. Eserin içeriği üzerinde uzun boylu durmaktansa, Abîdînin Lutfi Paşa’ya atıf yaptığı bir yerde söyledikleriyle Âsâfnâme'den bir pasajı beraberce dikkatlere sunmak istiyoruz. Abîdî şöyle diyor:

Lutfi Paşầ-yı münşı̂̀-i dîvan / Yánî̀ kim Âsaf-ı Süleyman Hân

Dedi olsa sadâret-i uzmâa / Vüzerâdan birine ger it tâ

Nice olmak gerek sadâretde / Ki safâ eyleye vizâretde

Şehriyârın tabîatın gözede / Amelin lâyık-ı sadâret ide

Hiçbir şahsa olmaya garazı / İde dilden izâle ol marazı

Çü sadâretde buldu lutf-i azîm / Gerek olmak âna halìm ü selîm

İde hükmünde emr-i bi'l-ma'rûf / Ola balk içre adl-ile mevsûf

Her kaçan padişah ile düstûr / Alsa gâhî tekellüme destûr

Nice itmek gerek tekellüm ol / Tâ ki Mevlầya ola makbul kul

Diye her hak kelâmı bünkâra / Havf idüb cismin atmaya nâra

Ger ana keșf-i râz ide hünkâr / Olmaya kimse vâkif-ı esrâr ${ }^{69}$

Bu mısraları, Lutfi Paşa’nın şu ibaresiyle karşılaşı ırdığımız zaman, Kânun-ı Hân Süleymân'ın Âsâfnâme'den ibaret olduğu ortaya çımaktadır:

"Evvelâ vezîr-i a'zam olanda garaz olmamak gerekdür. Ve her husûsu lillâh fillâh ve li-vechillâh itmek gerekdür. Zîrâ vezîr-i a'zamdan yukarı bir mansıb yokdur ki ana vâsıl ola. Ve hak sözü pâdişâha hicâb itmeyüb dimek gerekdür. Ve erkân-1

68 Eyledi derdmende çok ihsan / Azm idüb gitdi râzı vü şükrân

Ben dahi dâver-i cihânbânın / yảnî kim pâdişâh-ı devrânın

Lutf ihsânına tutub ümmîd / Nazmın dilde eyledim te'kîd

Kân-ı endîşeye o dem girdim / Anda genc-i meânîye erdim

Buldum anda neçe neçe cevher / Her birinin behâsı câna değer

Dürr ü yâkut u la l-i rummânı / Yani Kânun-ı Hân Süleymân'

Intihâb etmiş âsaf-ı a'zam / Lutfi Paşa-yı a'del-i ekrem

Eylemiş âna say ü dikkatler / İde Mevlâ garîk-i rahmetler

(Abdüssamed Abîdî, Hazâinül-Kanun, vr. 7b)

69 Abîdî, Hazâinül-Kanun, 17a’b. 
devleti cevâb-1 hakka işhâd itmek gerekdür. Ve pâdişâhile olan mükâlemesin ve îrâda mütéallik müşâveresin hâricden değil belki sâir vüzerâ bile bilmemek ve vâkıf olmamak gerekdür." ${ }^{’ 0}$

Lutfi Paşa'nın "kanunname” sine yapılan atıflardan bir diğeri ise, Abîdî̀den yaklaşık bir asır sonraya, 18. yüzyıl tarihçi ve müelliflerinden Şehrîzade Mehmed Said'e (ö. 1764) aittir. Şehrîzâde Tâcül-Kavânîn isimli eserinde, Sultan İbrahim devri ricalinden Abdüssamed Abîdînnin, Lutfi Paşa’nın kaleminden çıkan ve Kânunnâme-i Süleymânî şeklinde isimlendirdiği "meşhur" risalesine bazı mühim fevaid ilave etmek suretiyle nazm şeklinde hazırladığı ve ismini HazâinülKānûn koyduğu eserini zevkle okuduğunu ve kendisinin de bu eseri nesre çevirip hikmet ve ahlaka dair bazı ilaveler yaparak Tâcül-Kavânîn adını verdiği eserini kaleme aldığını anlatır. ${ }^{71}$ Görüldüğü gibi iki eser de yalnızca Lutfi Paşa’nın "kanunname" sine atıf yapmakla kalmayıp eserlerini bu çalışma üzerine bina ettiklerini söylemiş olmaktadırlar. Ayrıca Abîdînnin eserinin başlığında "kanun", Şehrîzâde'nin eserinde de bunun çoğulu olan "kavânîn” kelimesinin bulunması bir başka önemli noktadır.

70 Lutfi Paşa, Âsâfnâme, Kütükoğlu neşri, s. 5-6.

71 "Çün zimmet-i himmet-i zümre-i hayr-hâhân-1 devlet-i ebed-peyvend-i aliyyeye mesâbe-i farz-1 aynda bir ma'nâdır ki bâ iss-i teşyîd-i kasr-1 vâlâ-yı saltanat olan mevâddı inhâ vü iblâğ babında bezl-i makdûr ve ber ma'nâ-yı tahdîs-i ni'met-i bendegân-1 sadâkat-nişân-1 saltanat-1 seniyyeye sebeb-i nizâm-1 âlem olan umûru tebyîn hususunda sarf-1 say'-i mevfûr eyleyeler. Li-ecli zâlik bu abd-i hakîr-i kesîrü’t-taksîr ve dilsâde kim beyne'l-etrâb Şehrîzâde şöhretiyle mårûfdur, eb ${ }^{\text {en }}$ an cedd ${ }^{\text {in }}$ müstağrak-1 yemm-i eltâf-1 selâtîn-i devlet-i Osmâniyye dâmet fî savni's-Sübhâniyye'de olub vâsıl olduğum ni'am-1 bî-pâyâna teşekkür ${ }^{\text {en }}$ bu bâbda dahi bir eser-i cemîl vaz'ına dil-teşne olduğum esnâda eşbeh-i vüzerâ-i asr-1 bâhirü’n-nasr İskender-i sânî merhum Sultân-1 Süleymân-hânîde Lutfi Paşa-yı mağfiret-karîn cenâbının yâdigâr-1 kalem-müsşîn-rakamları olub Kânunnâme-i Süleymânî tesmiye etdiği risâle-i meşhûre-i müşgîn-kâlâlesin ricâl-i ahd-i İbrahim-hânîde Abîdî mahlas Abdüssamed nâm merd-i gayretirşâdın bazı fevâid-i mühimme zammılla keşîde-i silk-i tanzîm ve nâm ü târihin HazâinülKanun ile tefhîm etdüği makalesi ber-fehvâ-y1 إذا أراد الله شياً هيّأ أسبابه vâsıl-1 dest-i hakîr oldukda eğerçi nâzımına îsâr-1 dürer-i ed'iye-i firâvân ile sâpâş u âferîn kılınarak serâpâ mütâlaa olunmağla mûcib-i inşirâh-1 dil-i nâtüvân oldu. Lakin bu makûle umûru inhâda çendan fevâid-i melhûza misillü te'sîr olmadığı muhtâc-1 ta'bîr olmamağın makâle-i merkûme vükelâ-yı asra kavânîn-i Süleymânîyi li-ecli't-tezkîr kütüb-i hikmiyye ve nesâyih ü ahlâkda me'hûze bazı fevâid-i cemîle inzimâmiyle tensîr ve Tầü̈l-Kavânin ismiyle zebânzed-i sağîr ve kebîr kılınub..." (Şehrîzâde Mehmed Saîd, Tâaül-Kavânîn, Topkapı Sarayı Müzesi, Emanet Hazinesi, nr. 2064, vr. 2a-2b). 
Eserin muhtevası, Âsâfnâme’ninkiyle büyük ölçüde örtüşür. Şehrîzâde kendi devri açısından gerekli gördüğ̈̈ unsurlarla ${ }^{72}$ muhtevayı zenginleştirmiş, anekdotlar eklemiştir. Abîdînin eseri üzerinden Âsâfnâmé yi güncellemekle birlikte, doğrudan bu esere atıf yaptığı da vâkidir: "Müellif-i Âsâfnâme merhum Lutfi Paşa der ki..." ${ }^{\prime 3}$

Abîdî ve Şehrîzâde'nin eserlerinin, bilhassa da Tâcǘl-Kavânîn' in analizi müstakil çalışmaları gerektirir. Buradaki amacımız bakımından şu sonuca ulaşmak yeterlidir: Bu iki müellif Lutfi Paşa’nın "Kanunname"sinden Âsâfnâme' yi kastetmişlerdir. Bunu hem Paşàya atıf yaptıkları bağlamlardan, hem de eserlerin genel muhtevasından hareketle söylemek mümkündür. Katib Çelebi'nin ilgili atfını da Kânunnâme-i Osmânî başlığı altına girebilecek iki eseri arka arkaya sıralamak şeklinde yorumlamak kolaydır. Eserin 1941 tarihli baskısındaki ibare zaten ikisi arasında bir irtibat kurmamaktadır. Öyle anlaşılıyor ki, zaman içerisinde Âsâfnâme ile Ayn Ali Efendi'nin eserleri arasında, ikisi de bazı "kanun"ları ortaya koymaları itibarıyla bir irtibat olduğu düşünülmüştür. Yukarıda zikrettiğimiz Luvis Şeyho'nun neşrettiği Arapça Âsâfnâme baskısına temel teşkil eden yazma nüshada bu iki eserin bulunduğunu hatırlayabiliriz. Ayrıca Köprülü Kütüphanesi Ahmed Paşa bölümü 203 numaralı nüshada da Âsâfnâmè nin hemen ardından, hatta hiç boşluk bırakmaksızın Ayn Ali Efendi'nin eseri istinsah edilmiştir. Şeyho baskısında eserin genel başlı̆̆ının "Kânûn-1 Benî Osman" olduğunu, Arapça Âsâfnâme metninin başlı̆̆ının da "Kânûn-ı Lutfi Paşa" olduğunu hatırlatalım. Âsâfnâme muhtevasının yer yer devlet protokolüne ilişkin birtakım "kanun"ları açıklamayı hedeflediğini, eserde sık sık "kanundur" ifadesini kullandığını görüyoruz..$^{74} \mathrm{O}$ halde bütün bunlardan hareketle Lutfi Paşa’nın Âsâfnâme’den ayrı bir kanunnamesinin bulunmadığını, zaman içerisinde bu eserin bir nevi kanunname gibi kabul gördüğünü, belki de Şehrîzâde’nin ifadesiyle Kânunnâme-i Süleymânî şeklinde meşhur olduğunu söyleyebiliriz.

72 Mesela 16a'da "fi zamâninâ" diye başlayarak ulak-menzilci meselesinin kendi devrinde tezahür eden problemlerini anlatır: “... husûsen vüzerânın be-her sâl elli def'a memleketten memlekete intikallerinde derdmendlere olunan zulmün vasfı kâbil değildir...” Yine bir başka yerde şöyle der: "Abd-i hakîr derim ki: Bu tahrîrât ol vakte nazarandır. Fî asrinâ mukāta ât ber vech-i mâlikâne birer kimesnenin iltizamındadır." (34a)

73 Şehrîzâde, Tâcüll-Kavânîn, vr. 16a. Ayrıca 18b, 21b, 33a.

74 Tespitimize göre eserde 45 civarında "kanundur", 10 kadar da "kanun değildir" ibareleri geçer. 


\section{Lutfi Paşa'nın İlmî Yönü}

Lutfi Paşa eserlerini uzun mazuliyet hayatının sağladığı boş vakit sayesinde yazabilmiştir. ${ }^{75}$ Fuat Köprülü diyor ki: "Öyle görünüyor ki, Lutfi Paşa’yı müverrih ve müellif sıfatıyla tanımaklığımız, doğrudan doğruya bu mazuliyet hayatının semeresidir. Çünki böyle bir fırsat zuhur etmeseydi, kendi ifadesince, 'tahsil ettiği ulûm ve me'ârifi zuhûra' getiremeyecekti." ${ }^{76} \mathrm{Bu}$ mazuliyet hayatı olmasaydı onu bir İslam âlimi olarak tanımamız da mümkün olmayacak, sadece bir devlet adamı olarak anacaktık.

Fuat Köprülü, "Lutfi Paşa’nın şer‘iyyâta müte‘allik eserleri elimizde bulunmadığı cihetle, bu hususlardaki vukuf ve malumatının derecesini tayin tabii kâbil değildir."77 demektedir ki, yukarıda eser listesinde yaptığımız açıklamalardan anlaşılacağı üzere bu eserlerden birçoğu günümüze ulaşmış olmasına rağmen, bugüne kadar Paşa'nın İslâmî ilimlere dair telifatı herhangi bir değerlendirmeye konu olmamıştır. Umûrü'l-Mühimmât ile ilgili soru işareti bir tarafa, Türkçe eserlerinin tamamen, Arapça eserlerinden de aralarında en önemlisi olan Zübdetül-Mesâil in bulunduğu birkaç tanesinin günümüze ulaştığı, dokuz Arapça risalenin kaydına ise henüz ulaşamadığımız görülüyor. Lutfi Paşa'nın eserlerine dair bu liste içerisinde birbiriyle yakından ilişkili eserler bulunduğu anlaşılmaktadır. Yukarıda zikri geçtiği üzere, 2, 3 ve 18 numaralı eserler arasında kısmen özdeşlik ve tercüme ilişkisi bulunmaktadır. Ayrıca Arapça risalelerinden bir kısmının isimleriyle,

75 Osmanlılarda Lutfi Paşa gibi kul kökenli bir devlet adamı bir tarafa, ömrünü ilim tahsil ve tedrisine vakfeden ulemanın "akademik performansı" 16. yüzyılın sonunda Gelibolulu Âlî tarafından eleştiri konusu edilmiştir. Gelibolulu, ilmiyedeki intisap ve mülazemet sisteminin doğası, müderrislik gibi mansıpların köşesine çekilerek telif ve tetebbuya kendini verenlere değil nüfuz sahipleriyle yakın olup kendini gösterenlere tevcih edilmesi, ulemanın makam ve para peşinde koşması gibi sebeplerle yaşadığı devirde yetkin müelliflerin azaldığı ve telif performansının sayısının düştüğü kanaatindedir (Gelibolulu Mustafa Âlî, Nushatu's-Selâtîn, haz. Andreas Tietze, Mustafā 'Älì̉s Counsel for Sultans, I/175-177; Kasım Ertaş, Gelibolulu Mustafa Âlînin Nasîhatü'sSelâtîn İsimli Eserinin Tenkidli Metni (yayınlanmamış yüksek lisans tezi), s. İstanbul 2008, s. 110112). 16. yüzyıldan itibaren gerçekten de verimli bir telif hayatı geçiren ulemânın, daha ziyade Birgivî Mehmed Efendi gibi kanaatkâr bir ömür süren, yahut Müstakimzade Süleyman Sadeddin Efendi gibi sistemden dışlanan isimler arasından çıktığı söylenebilir.

76 Köprülü, s. 130.

77 Köprülü, s. 142. Serhan Tayşi de aynı hükmü tekrarlamaktadır (s. 21). Ancak Köprülü iki sayfa sonra "Lutfi Paşa'yı, alelade bir telfîk ve ta’mîm mahsûlü olan müellefât-1 şer'iyyesinden ve değersiz manzumelerinden ziyade, Âsafnâmessi ve Tarib’i ile nazar-1 itibara alarak bir müverrih gibi tedkik etmek şüphesiz daha doğrudur” (s. 144) demek suretiyle kendisiyle çelişkiye düşmektedir. 
Zübdetül-Mesâil in bazı bab başılıları arasında bir yakınlık görülmektedir. Dolayısıyla bazı risalelerin, aslında ayrı birer eser olmayıp geniş hacimli eserlerin bazı bölümlerinin belki bazı tasarruflarla ayrı bir "neşr"i olması da muhtemeldir.

Kaynaklarda Lutfi Paşa’nın iyi bir Arapça tahsil gördüğü ve İslâmî ilimlere, bilhassa da fikıh ilmine meraklı olduğu belirtilir. Ayrıca onun Farsçàyı da iyi bildiği anlaşılmaktadır. Kilisli Rifat Bilge, Paşånın Farsça bir eseri bulunmamasından hareketle onun bu dil ile meşgul olmadığı kanaatine varıyor. ${ }^{78}$ Eğer bu ifadesiyle onun Farsçàyı bilmediğini kastediyorsa bu doğru değildir. Nitekim Zübdetül-Mesâilde ${ }^{79}$ ve Risâletüll-Kunûz'da ${ }^{80}$ bazı Farsça ibareleri örnek vermesi onun bu dili bildiğini gösterir. Arapça olarak kaleme aldığı Zübdetüll-Mesâilin kurbanlarla ilgili bir yerinde Lutfi Paşa Türkçe olarak şöyle yazar: "Müellif-i Fetâvâ-i Tatarhâniyye bu mahalli Arabîyle takrîr etmeyüb Fârisîyle tahrîr eylemiştir. Bu hakîr dahi elden geldikçe Fârisîden Türkîye terceme idüb bu üslub üzre kaleme getürdü." Müellif buradan itibaren iki sayfa boyunca Tatarhaniyye'deki Farsça ibareyi Türkçeye çevirmiştir. ${ }^{81}$

Lutfi Paşa, medresede eğitim görmeden İslâmî ilimlerde yetişen bir simadır. Kendisi Tevârih-i Âl-i Osman adlı eserinin girişinde, Sultan Bâyezid zamanında henüz çocukken saraya alındığını ve Sultan Selim tahta çıkıncaya değin eğitimiyle meşgul olduğunu belirtir ("nice zaman maârife sa'y olunub emekler çekildi.") Âsafnâme'deki şu ifadelerinden, Enderun'daki eğitimini tamamlayıp çeşitli devlet hizmetleri görürken de âlim ve kültürlü kişilerden istifade etmeye devam ettiği anlaşılmaktadır:

"Bu risâlenin müellifi ez'af-1 'ibâdullah Lutfi Paşa bin Abdülmuîn vaktâ ki harem-i hass-1 sultânîde bu hakîr merhûm ve mağfûr ${ }^{\text {un }}$-leh cennet-mekân u firdevs-âşsiyân Sultân Bâyezîd Han hazretleri zamânından beri perverde-i ni'met-i sultânî olub bu Âsitâne-i 'Osmâniyye'ye lillâh hayrhâh olup ve harem-i hassda iken niçe zamân tahsîl-i maârif idüb ve cülûs-1 Hazret-i Sultân Selîm Hân hayâtında

78 Kilisli Muallim Rifat, "Müellife ve Kitaba Dair Birkaç Söz" (Tevarihìn 1341 neşrine takdim), s. 3.

79 vr. 190a, 214a'b, 229a.

80 vr. $27 \mathrm{~b}, 50 \mathrm{a}, 64 \mathrm{~b}$.

81 Lutfi Paşa, Zübdetüll-mesâil, 136a-138a. Paşa, sözünün sonunda şöyle diyor: "Müellif-i Fetâvâ-yı Tatarhan[iyye] bu mahalli kitabında Fârisî-dil üzre yazmağın ana binâen biz dahi bunu Türkî-dil üzre tercüme idüb münasebetle bu mahalle yazdık."

82 Lutfi Paşa, Tevârih-i Âl-i Osman, 1; 142 (ilk rakam Âlî Bey neşrinin, sonraki rakam Kayhan Atik neşrinin sayfa numaralarına atıf yapmaktadır). 
çukadarlıkdan elli akçe müteferrikalık ile taşra çıkub ba'dehû çaşnigîr-başılık, ba'dehû kapucu-başılık, ba'dehû mîr-i 'alemlik, ba'hehû Kastamonu Sancağı, andan sonra Karaman Beğlerbeğisi, andan sonra Anadolu Beğlerbeğisi, andan sonra vizâret 'inâyet olundu. Ba'dehû pâdişâhımız Sultan Süleymân Hân zamanında sadâret-i 'uzmâ ('inâyet) olundu. Bu hakîr-i kesîrü't-taksîr taşra çıkdıkda niçe 'ulemâ vü şu'arâ vü zürefâ ile musâhabet ve münâsebet idüp 'alâ kadri't-tâka niçe maârif ü tahsîl-i 'ulûm itmekle taltîf-i ahlâk itmiş idim." ${ }^{3}$

Sehî Bey (ö. 1548), Heşt Bihişt isimli şuara tezkiresinde Lutfi Paşa’nın ahlâkını, dindarlığını, zekâsını ve ilmini uzun uzun över. ${ }^{84}$ Lutfi Paşa’nın bir diğer çağdaşı Celâlzade Mustafa Çelebi (ö. 1567) de, Paşa’nın azl ve nekbet devrinde kaleme aldığ ${ }^{85}$ eserinde, Lutfi Paşa'ya dair, bilhassa onun ilmî yönüyle ilgili olarak tarih kitabının çeşitli yerlerinde çok olumlu ifadeler kullanır; mesela bir yerde şöyle der: "Lutfi Paşa ki zihn-i pâki âyine-i mücellâdır ki çehre-i hakâyık-ı eşyâ kemâ hiye anda mahbûs, tab'-1 derrâk-i tâbnâki mir’ât-1 cihânnümâdır ki eşkâl-i ahvâl-i cumhûr mu'âyenen anda ma'kûsdur. Zât-ı meâlî-sıfâtı ulûm-i dîniyye[ye] mecma' ve cûd-1 menâkıb-âyâtı mihr-i devlet ü ifdâle matla 'dır." 86

Gelibolulu Mustafa Âlî (ö. 1600) ise Lutfi Paşa hakkında olumsuz değerlendirme yapan yazarların muhtemelen ilkidir. Paşa’nın diğer paşalara nispetle sarf ve nahiv okuduğunu, hatta Hanefî fikhına dair klasik eserlerden Kenz ve Kudîrî ve Münyetüll-Musallî kitaplarını "gördüğünü” söyler. Mustafa Âlî, Lutfi Paşa’nın kendini ilim sahasında devrinin ulemasından üstün gördüğü iddiasındadır. Beyzâvî ve Zemahşerî gibi İslam tarihinin büyük ulemasıyla kendisini aynı mertebede gördügünü, Aşcızade Hasan Çelebi ve Ebussuud Efendi gibi devrinin büyük âlimlerine bazı kelimeler sorduğunu, onların mânidar sükutlarını cehaletlerine hamledip "şaşılacak şey, bu iki mollanın şöhreti ilimlerinden fazla; bilmedikleri çok, bildikleri nadir imiş" dediğini nakleder. ${ }^{87}$ Mustafa Âlî̀nin bu

83 Lutfi Paşa, "Asafname", s. 1-2.

84 Heşt Bihişt, s. 122-123.

85 M. Tayyip Gökbilgin, "Lutfi Paşa”, VII, 100.

86 Celâlzâde Mustafa, Tabakâtü̈l-Memâlik ve Derecâtül-Mesâlik (Geschichte Sultan Süleyman Kanunis von 1520 bis 1557, nşr. Petra Kappert, Wiesbaden: Franz Steiner Verlag, 1981), 285b. Celâlzade aynı eserde başka vesilelerle de (301a ve 311a) Paşa'yı tumturaklı ifadelerle över.

87 "Eğerçi sâir paşalara nisbet nahv ü sarf okumuş idi. Hatta kütüb-i fikhiyyeden Kenz ve Kudûrî ve Münyetü’l-Musallî kitablarını görmüşdü. Ve illâ da‘vâ-yı tefadduldan hâlî değil idi. Kendünü Kadı Beydâvî ve Keşşâf-ı Zemahşerî mertebesinde bilürdü. Ol tarihde olan ulemâdan Aşcızade 
yaklaşımı sonraki tarihçilerin Paşa hakkındaki görüşlerini de etkilemiştir. Fleischer, Âlînnin bu menfî kanaatinin temelinde, onun Osmanlı eğitim sistemindeki dönüşüme dair muhafazakar görüşünün yattığı düşüncesindedir.

"16. yüzyılın ortalarına değin bütün eğitimin yalnızca medrese ile bağlantılı geleneksel İslami özellik taşıdığı açıktır. Bununla birlikte medrese tedrisatının bazı öğeleri saray eğitim sistemine dahil edilmişti ve bu nedenle Lutfi Paşa gibi devşirme kökenliler bile nizami medrese eğitimi görmedikleri halde âlimlik iddiasında bulunabiliyordu. 16. yüzyılın ikinci yarısında bürokrasi de, daha önce yalnızca medresede edinilebilen eğitimin belirli bir çekirdek bölümünü varsayan ya da içine alan bir uzmanlık eğitimiyle profesyonelleşme, ya da Osmanlılaşma sürecinden geçmişti. Âlî̀nin Lutfi Paşa’nın âlimliği ve meslekten bürokratların niteliğine ilişkin görüşleri eğitimin Osmanlılaştırılması olarak nitelenebilecek bu gelişmeleri kabullenemediğini gösteriyor. Onun için gerçek ilim yalnızca medrese demekti." ${ }^{38}$

Rifáat Ali Abou-el-Haj da Fleischer' in kanaatini teyit eder ve Mustafa Âlînnin, kendi çağında Osmanlı bürokrasisindeki tayin ve yükselmelerle ilgili kuralların değişip genişlemesine tepki duyduğunu vurgular.

"Söz konusu kuralların, Kanuni Süleyman dönemi ortalarında var olan medrese sisteminin bir ürünü olan Âli’nin umduğundan farklı olduğu anlaşılmaktadır. Kuşkusuz ki Âli deneyimli bir bürokrat ve çevresinde olup bitenlerin sağlam bir gözlemcisiydi; buna rağmen, bir kişinin şahsi ve siyasi yaşamının doğrudan etkilendiği bir zamanda, değişmenin genel niteliğini ve boyutlarını algılaması, değerlendirmesi kolay değildir." ${ }^{’ 9}$

Peçevî de, muhtemelen Gelibolulu Âlî̀ye dayanarak, Lutfi Paşảnın ilmî yönünü istiskal eder ve kendini devrinin en büyük âlimi zannettiğini ileri sürerek ağır ifadeler kullanır: "Bir mikdar sarf u nahv görmekle kendüyi allâme-i asr sanub kibâr-1 ulemâdan meclisine gelenlere kelime sorar dururdu. Ve bu vechi-

Hasan Çelebi'ye ve müfessir ü muhakkık-1 hudâ-dâdî Mevlânâ Ebussuûdü’l-İmâdî gibi fâzıla ahyânen kelime sorardı. Anlar dahi 'Cevâbü'l-ahmak sükûtur' mazmûnuna rağbet gösterdikçe, 'Aceb ki bu iki monlanın namları zatlarına âlîdir, zira ki mechulleri vâfir ve ma'lumları nâdir idüğü tahkikke mütekāribdir' deyu söylerdi.” (Mustafa Âlî, Künhüll-Ahbâr, 358a).

88 Cornell Fleischer, Tarihçi Mustafa Âli (İstanbul, Tarih Vakfi Yay., 2001), s. 281.

89 Rifa'at Ali Abou-el-Haj, Modern Devletin Doğası (çev. Oktay Özel-Canay Şahin, İstanbul, 2000), s. 60-61. 
le hâss u âmma sefâhetin izhar edüb ba 'dehû azl olunub tekâüd verilmiş idi."’0 Müneccimbaşı Ahmed Dede de yine muhtemelen Âlî̀den etkilenerek benzer bir değerlendirme yapar: "Nahv ve sarf ve fikıh ilimlerine dahi cüz'î müşâreketi olub lâkin ilmine gâyet i'tinâsı var idi."'11 Bursalı Mehmed Tahir Bey'e göre ise, rakip ve hasımlarının Lutfi Paşa hakkında sert yaratılışlılık (huşûnet-i tab'), kendini beğenmişlik, ilmine mağrurluk "gibi icad ettikleri tezvîrat" sadaret makamında devam etmesine engel ve ayrıca bu gibi tezvirat padişahla akrabalığına da son veren âmil olmuştur. ${ }^{92}$

Eserleri incelendiğinde Lutfi Paşa’nın devrindeki ulemâyı tahfif ettiğine dair bir şey göremesek de, aklına takılan meselelerle ilgili tanıdığı âlimlere soru sorduğuna dair Tenbîhül-Âkılîn isimli eserinde rast geldiğimiz -biyografisinin kimi noktalarına da ışık tutan- bir anekdotu paylaşmak istiyoruz. Lutfi Paşa Ebu Hanife'nin el-Fikhu'l-Ekber'inden, Cenâb-1 Hakk'ın "yed" hariç bütün sıfatlarının Farsça olarak ifade edilebileceği şeklinde bir görüş naklettikten ${ }^{93}$ sonra şöyle devam ediyor:

"Bu hakīrin gönlüne geldi ki ulemâ rahimehumullah Bârî Teâlâ’nın -azze ismuhu- müteşâbihâtda olan sıfatlarını Fârisîyle ta'bîr olunmasın câiz görüb, yed s1fatı ne sebebden Fârisîyle ta'bîr etmesin câiz görmediler? diyu müşkilimiz olmuş idi. İstanbul'da ve Edirne'de nice kimesnelerden sual olundukda murâd üzre cevab değmeyüb müşkilimiz hall olunmayub kalmışıdı. Tâ şol vakte değin ki, Hicret'in dokuz yüz kırk sekiz senesinde bu fakīrin uhdesinde olan vezâret hizmetin pâdişâh-1 âlem-penâh âhar kullarına tefvîz idüb bu hakīre hacc etmesine icazet virdiler. Müşkil olan mesâil-i mezkûrı yolda ve izde bazı kimesnelerden sorub cevablarından kanaat gelmemiş idi. Tâ Mısır şehrine gelinceye değin. Ve Mısır'da dahi bazı azîzlerden sual olundukda dediler ki: 'Allahu Teâlâ a'lem, 'yed' Fârisîyle 'dest' demek olur. Lügât-1 müşterekedendir. Arab ıstılâhında dest nice nesneye derler. Biri bu ki, nice kimseler bir yerde meclis edüb otursalar ol meclise dest derler. Ve biri dahi mesâlih-i memleket içün yazıcılar cem`olunduğuna dest derler. Ve dahi kazana dest derler. Ulemâ bunlardan kaçar, ve beni yede dest diyü ta'bîr olunmasın câiz görmediler ola' diyu cevab verdiler." ${ }^{\text {94 }}$

90 Tarih-i Peçevî, I, 21.

91 Müneccimbaşı Ahmed Dede, Müneccimbaşı Tarihi, III, 518.

92 Bursalı Mehmed Tahir, Osmanlı Müellifleri, III, 132.

93 Bu ibare için bkz. İmâm-ı Azam’n Beş Eseri (nşr. Mustafa Öz, İstanbul, 1992), s. 59.

94 Lutfi Paşa, Tenbîhül'-Âkılîn, (Kürkçüoğlu), vr. 43b-44a; (Ali Emirî), vr. 37b-38a. 
Kâtib Çelebi'nin Süllemü'l-Vusûlde Lutfi Paşa'yı bir müellif olarak ele almaması, onun ismini yalnızca bir defa, Ablâk-ı Süleymânî müellifi Fevrî Ahmed'den (ö. 1571) bahsederken zikretmesi ${ }^{95}$ ilginçtir. Keş̧üz-Zunûn'da da belli başlı eserlerine değinilmez, ismi yalnızca iki defa geçer.

Fuat Köprülü Lutfi Paşa’nın ilmî yönünü değerlendirirken, onun Sehî Bey ve Celâlzâde Mustafa gibi muasırlarından ziyade Gelibolulu Mustafa Âlî’yi dikkate alır:

\begin{abstract}
“Kilisli Rifat Bey’in, müellefâtına bakarak, Paşa’yı 'alelusul ders görmüş’ addetmesi yanlış olduğu gibi, 'Ebussuud, İbn Kemal gibi en büyük âlimlerin gözü önünde dinî eserler yazmasından dolayı büyük bir kudret-i ilmiyyeye mâlik olacağını' istidlâl etmesi de, hiçbir suretle doğru değildir. Bir defa bu eserler İbn Kemal'in vefatından epey sonra yazılmıştır. Sâniyen, Âlî gibi o devri gayet iyi bilen bir müverrihin şehadeti, şüphesiz biraz mübalağalı olmakla beraber, muasır ve haleflerinin Lutfi Paşa hakkındaki kanaatlerini açıkça göstermektedir. (...) Bütün bu rivayetlerden şu netice çıkarılabilir: Lutfi Paşa ulûm-i şer’iyyeye bîgâne bir adam olmamakla beraber, tab'an fazla mağrur ve hodpesend olduğundan, kendi iktidâr-1 ilmîsine lüzumundan pek çok fazla kıymet ve ehemmiyet veriyordu. Eserleri meydana çıkarılarak tedkik ve aksi isbat olununcaya kadar, eski müverrihlerin bu hususdaki müşterek kanaatlerine iltihak zaruretindeyiz." ${ }^{\text {96 }}$
\end{abstract}

Paşa’nın eserlerinin önemli bir kısmı bugün elimizdedir. Bu eserler üzerinde yaptığımız incelemelere dayalı olarak şunları söyleyebiliriz:

1. Gelibolulu Mustafa Âlî ile ona dayanarak Lutfi Paşa'nın ilmî yönünü eleştiren tarihçilerin söyledikleri iki noktada toplanır: i) Diğer paşalara nispetle sarf ve nahivle daha çok meşgul olup Hanefî fıkhına dair birkaç kitabı üstünkörü okuduğu, ii) İlmine mağrur olup kendini devrinin ulemasından üstün gördüğü.

Birinci noktayla ilgili olarak, Paşa’nın eserleri gözden geçirildiğinde onun İslâmî ilimlerle irtibatının yüzeysel, birkaç kitap okumakla sınırlı bir alâka olmadığını rahatlıkla söyleyebiliriz. Eserlerinde fıkıh, kelâm, tefsir, tasavvuf gibi sahalara ait çok sayıda esere atıf yapılmaktadır. Ayrıca Arapça'yı yanlışsız denebilecek bir rahatlıkla yazabildiğini görüyoruz.

95 Kâtib Çelebi, Süllemü̉l-Vusûl, I, 162. Kâtib Çelebi burada Fevrînnin bir köle olarak Lutfi Paşàya satıldığını ve onun tarafından azad edildiğini kaydeder.

96 Köprülü, s. 142-143. 
Kendini devrinin ulemasından büyük görüp görmediğine gelince; Âlî̀nin zikrettiği Aşcızade Hasan Çelebi ve Ebussuud Efendi gibi âlimlere soru sorup bilgilerini ölçtüğü hadisesini, bir tarihî hadise olması bakımından kritik edecek, böylece Âlî̀yi doğrulayacak veya yanlışlayacak başka anlatılar bulamıyoruz. Bu iddiayı Paşa'nın eserlerinden hareketle tahkik etmek istediğimizde ise, bu eserlerde devrin ulemasına yönelik bir atıf göremediğimizi söylemek gerekir. Dolayısıyla Paşa’nın Ebussuud gibi âlimlerle ilgili kanaatini kendi yazdıklarından hareketle öğrenemiyoruz. Diğer taraftan bu eserlerde dikkatimizi çeken bir husus, müellifin "zelîl, zaîf, hakîr, fakîr, bî-mikdâr" gibi tevazu ifadelerini bolca kullanmasıdır. Bunun devrin klişeleşmiş bir yazım tekniğinin yansıması mı, yoksa Paşa’nın kendi ilmî birikimi hakkında samimi bir kanaati mi olduğunu kesin bir şekilde bilmemiz mümkün değildir. Ancak ilmine çok güvenen bazı âlimlerin bu tarz tevazu ifadelerini kullanmakta çekingen davrandıklarını, Paşa'nın da iddialı bir üslup kullanmayı istediği takdirde, ilmiye mesleğine mensup bir şahıs olmadığına, bu alanda tedris veya kaza gibi bir ikbal beklentisi bulunmadığına göre, böyle yapmasına engel bir durumun bulunmadığını söylemek gerekir. Hayât-ı Ebedî adlı eserinin sonunda, zamanın ulemasını hatası varsa düzeltmeye samimi bir şekilde şöyle davet ediyor: "Ve ol ihvân-1 safâ ve eshâb-1 vefâ ve ulemâ-i asr ve fuzalâ-i dehrden umulan budur ki bu risâle nazarlarına yetiştikde dostluk gözüyle nazar ideler. Eğer hata ve noksan ve sehv-i kalem vâki` oldu ise hatasını ve noksanını ıslah ideler ve düşmenlik gözüyle nazar idüb uyûbumuzu istemelü olmayalar. Zira insan âcizlikden ve za'aflığından ve hatasından hâlî değildir." lerini kaleme alış keyfiyetinden bahsettiği birçok bağlamda "cem etmek" ibaresini kullanır ki, orijinal bir eser vermekten çok, daha önce yazılmış bilgileri toplamak, derlemek şeklinde bir anlam ifade eder. Bunlardan başka, eserlerini inceleyebildiğimiz kadarıyla, kendi ilmî şahsiyetini ön plana çıkaracak ibareler (söylediğinin kendi fikri veya tercihinin bu yönde olduğu, kendinden önce kimsenin böyle bir şey söylemediği, muteber bir alimi eleştirme vesilesiyle düşüncesini tebarüz ettirmesi vs.) kullanmadığını, eserlerinin kıymetini kaynaklarının muteberliğine dayandırdığını görüyoruz. Mesela yine Hayât-ı Ebedîde şöyle diyor: "Ve siz şöyle zann itmen ey benim azîz karındaşlarım ki biz bu risâlede kendü re’yimizle bir söz söylemiş olavuz. Belki bunun her bir sözü kütüb-i mu'tebereden istihrac olunub mahalli mahallinde zikr olunub yazılmışdır." ${ }^{88}$ Tenbîhül-Âkılîn'de de bazı muteber kaynakları saydıktan sonra "Bu hakīr dahi tâkati yetdikce anlardan bulduğu

97 Lutfi Paşa, Hayât-ı Ebedî (Ali Emiri), vr. 53b.

98 Lutfi Paşa, Hayâtı Ebedî̀ (Ali Emiri), vr. 55a. 
rivayet üzre bir bir takrîr ideriz inşaallahu teâlâ" der. ${ }^{99}$ Yine aynı eserin sonunda, eserini okuyanların kendisine dua etmelerini ve kitabı insaf nazarıla okumalarını rica ederek şöyle diyor: "Ve insaf ideler ki bu asl-ı kitâb Türkî-dilde işitilmiş ve görülmüş değildir. Ve bunu nice muteber yerlerden cem' edince hayli çok zahmet çekilmişdir." ${ }^{100}$

Şu halde, Lutfi Paşąnın kendini Ebussuud Efendi gibi devrinin büyük âlimlerinden üstün görüp görmediğini kendi eserlerinden hareketle teyit edemiyoruz. Çağdaşların birbirleri hakkındaki değerlendirmelerini ihtiyatla karşılamak gerektiği dikkate alınacak olursa, Gelibolulu Âlînnin ifadelerini yok saymak da tamamen kabul etmek de kolay değildir. Onun ilmî yönünü Ebussuud ve İbn Kemâl gibi zevatla kıyaslamak ne kadar yanlışsa, tamamen gözardı etmek de o kadar yanlıştır. İslâmî ilimlere dair günümüze ulaşan eserleri, onun bu sahadaki mesaisinin biraz sarf ve nahiv görüp birkaç kitap okumanın çok ötesinde olduğunu gösterir.

2. Lutfi Paşa bazı eserlerinin sebeb-i telifi olarak, bazı dostlarının (msl. "ashâb-1 vefâ ve ihvân-1 safâ") kendisinden belirli bir konuda kitap telif etmeyi istemelerini gösterir. Eğer bu bir telif kurgusu değilse, bu tarz ifadeler, Paşa'nın Dimetoka'da dînî konuları konuştuğu bir çevresinin bulunduğunu, bu insanların kendisini eski bir devlet adamından ziyade, dinî bir otorite olarak gördüklerini gösterir.

3. Paşånın eserleri genellikle fikıh ve kelâm ilimlerinin sahasına, itikad ve ibadet esaslarına dairdir. Ehl-i sünnetin özellikleri, elfaz-1 küfür gibi konular da önemli temalar arasındadır. Paşa eserlerinde didaktik bir gaye gütmektedir. Özellikle Türkçe eserlerinde geniş halk kesimlerine faydalı olmayı amaçlamaktadır. $\mathrm{Bu}$ amacının eserlerde kullandığı dile de yansıdığını, mesela Âsafnâme gibi diğer Türkçe eserleriyle kıyaslandığında, Paşa’nın dinî ilimlere dair yazdığı Türkçe eserlerinin dilinin biraz daha sade olduğunu, Arapça ve Farsça kelimelerden ziyade Türkçe kökenli -zaman zaman arkaik- kelimelere daha fazla yer verildiğini söyleyebiliriz.

4. Lutfi Paşa Osmanlı hanedanına karşı olan minnetini eserlerinde çeşitli vesilelerle ifade eder. ${ }^{101}$ Sultan Süleyman'a bağglılı̆ıını ortaya koyduğu ifadelerini

99 Lutfi Paşa, Tenbîhül-Âkılîn (Kürkçüoğlu nüshası), vr. $24 \mathrm{~b}$.

100 Lutfi Paşa, Tenbîhül-Âkılîn (Kürkçüoğlu nüshası), vr. 58a; Ali Emiri nüshası, vr. 52a.

101 Mesela Âsafname'de şöyle der: "perverde-i ni'met-i sultânî olup bu Âsitâne-i 'Osmâniyye’ye

li’llâh hayrhâh olup”. Tevârib'de (s. 4 vd.) Osmanoğullarının faziletlerinden bahseder. 
görev beklentisi şeklinde yorumlamak mümkünse de şayet yeni bir göreve getirilmek yönünde bir ümidi var idiyse, böyle bir ümidin kesilmiş, en azından epeyce azalmış olması tabii karşılanacak kadar uzun bir zaman, yani on iki yıl sonra kaleme aldığı Halâsü'l-Ümme’de, Kanuni'yi uyulmaya layık yegâne dinî otorite olarak takdim etmesini, İslamın sahih biçimde ancak güçlü bir devlet nizamı altında yaşanabileceğine olan kanaatiyle açıklamak akla daha yatkın görünmektedir. Tarihî ve siyasî eserlerinde, bu hanedanın başında olduğu Osmanlı Devleti'nin birlik ve bütünlüğüne vurgu yapması, dinî eserlerinde Ehl-i sünnet vurgusu ve bidatçı fırkalara karşı sert tutumu, Yavuz Selim'in Şah İsmail ile kavgasından itibaren Osmanlıların üstlendiği Sünniliği koruyup temsil etme ideolojisiyle uyum içindedir. Tevârîh'de ortaya koyduğu tecdîd anlayışı ise bütün bu gözlemleri destekleyip ileri götüren, onun din ile devleti birbirinden ayrılmaz bir bütün şeklinde telakki ettiğini gösteren bir olgudur. Onun dini yenileme, dolayısıyla dini temsil makamı olarak siyaseti (hükümdarları) görmesi, üzerinde başlı başına durulması gereken bir husustur. Onun bu tavrına mukabil kendisiyle çağdaş Taşköprîzâde gibi bazı ulemânın siyasete karşı ulemâ merkezli din söylemi ve siyaset (mutlakiyetçilik) eleştirisini, ${ }^{102}$ mukayeseli çalışmaların konusu yapmak gerekir.

5. Yukarıdaki maddede söylenenlerle de irtibatlı olarak, Lutfi Paşa eserlerinde çözülmesi gereken meseleleri çözmekten, içtihad etmekten, tahkîk ve tercih etmekten, söylenmemiş bir şeyler söylemekten ziyade, muteber görüşlere dayanan, dinin genel kabul görmüş çerçevesine işaret eden, sahih dinî tavrı öğreten bir tutum sahibidir. Bununla birlikte Zübdetül-Mesâil ile Halâsül-Ümme’deki bazı tahkikatı bu çerçeveyi zorlayan bir nitelik taşır.

6. Lutfi Paşa’yı, aynı yüzyılda yaşayan İbn Kemal, Birgivî, Taşköprîzade ve Ebussuud Efendi gibi büyük ulema ile mukayese etmek doğru değildir. Paşa’yı Osmanlı ilim ve kültür tarihi içerisinde orijinal yapan taraf, ismi sayılan âlimler gibi ömrünü ilimle geçirmiş, küçük yaşta ilmiye mesleğine sâlik olup medreselerde ilim tahsil etmiş bir insan olmayıp sarayda yetişen bir devşirme ve veziriazamlığa kadar yükselen bir devlet adamı olarak İslâmî ilimlerle bu derece meşgul olabilmesi, Arapça’yı yalnız okuyabilecek kadar değil rahatlıkla ve akıcı şekilde eser yazabilecek kadar bilmesi, müesses Osmanlı nizamı içerisinde âlim olarak yetişmesi beklenmeyen seyfiye içerisinden âlimlik iddiasıyla ortaya çıkarak farklı bir âlim portresi çizebilmesidir. Gördüğü tepkiler, hakkındaki ithamlar belki biraz

102 Bu hususta bkz. Asım Cüneyd Köksal, "Taşköprîzâde'de Akıll, Siyaset ve Tarih” (İnsan ve Toplum (2017), c. 7, sy. 1), s. 242-246. 
da bu farklılık sebebiyledir. Eserlerinden Zübdetül-Mesâil ile Risâletüll-Künûz gibi bazılarını sözgelimi Birgivî gibi bir âlim yazmış olsaydı, çok daha fazla tanınıp rağbet göreceği kuvvetle muhtemeldi.

\section{Lutfi Paşa’nın Eserlerinde Atıf Yaptığı Kaynaklar}

Lutfi Paşa'nın eserlerinde kullandığı kaynakları tespit etmek, onun ilmî tecessüsünün sınırları, İslâmî ilimlerle meşguliyet derecesi hakkında bir fikir verebilir. Bu amaçla onun İslâmî eserlerini inceleyerek kaynaklarını tespite çalıştık. Bu liste, aynı zamanda onun ilmî şahsiyeti hakkında Âlî ve onu takiben diğer yazarların değerlendirmelerini de bir yönden test etme imkânı sağlayacaktır. Listeyi takdim etmeden önce, Paşa’nın hilâfet meselesini açıklığa kavuşturmak amacıyla kaleme aldığı Arapça Halâsül-Ümme adlı eserinin girişinde, risaleyi yazarken kullandığı kaynakları zikrettiği bir pasajı aktarmak istiyoruz:

“...onların bu yüce arzularını yerine getirmek istedim ve hak ile bâtılı birbirinden ayıran muteber kitaplarda konuyla ilgili bir araştırma yaptım. Araştırmama konu olan kitapların listesi şöyledir:

Fetava Kâdıhan, Fetava Mecma'il-havâdis vèn-nevâzil ve'l-vâkı'ât, Ebu'l-Leys'in Fetâve’n-nevâzil'i, el-Fetâve't-Tatarhâniyye, Fetâve'l-muhît, Fetâve'l-vecîz, el-Fetâve'lBezzâziyye, Câmi 'u'l-fetâvâ, Bedâi 'u's-sanâ i fî tertîbişs-şerâi', el-Hidâye, el-Muhtârât, et-Tevfik, Zahîratül-ukbâ, Zübtedül-mesâil.

Hadis kitaplarından ise Şerhu'l-Meşârık ve'l-mesâbîh adlı eserlere başvurdum. Bunlar dışındaki kaynaklarım ise Şerhu Şir'ati'l-İslâm, İbn Cerir et-Taberi'nin et-Tevârîh'i, el-Fevâihu'l-miskiyye fi'l-fevâtihi'l-mekkiyye adlı eserdir. Ayrica etTa'rifât' a ve lügat kitaplarından el-Kâmûs'a da başvurdum." ${ }^{103}$

Aşağıda Lutfi Paşa’nın İslâmî ilimlere dair eserlerini kaleme alırken kullandığı kaynakları, kendi yaptığı atıfları dikkate almak suretiyle meydana çıkarmayı hedefleyen bir liste takdim ediyoruz. Liste, kitap isimlerine göre alfabetik olarak düzenlenmiştir. Müellif hemen her cümlesinin kaynağını belirtmektedir. Bu sebeple onun eserlerindeki atıf sayısını binlerle ifade etmek mümkündür. Bu itibarla listede yer alan eserlerin adının geçtiği her yer belirtilmemiş, her eserle ilgili olarak temsil edici sayıda atıfla iktifa edilmiştir. Lutfi Paşa'nın birden fazla nüshası bulunan eserlerinde hangi nüshaya göre referans verildiğine, eserin ilk geçtiği yerde

103 Lutfi Paşa, Halâsü'l-Ümme, Süleymaniye Ktp., Ayasofya, no. 2877, vr. 3a-3b. 
işaret edilmiştir. Müelliflerinden emin olmamakla birlikte bir müellife ait olduğunu muhtemel gördüğümüz kitaplarda müellif adının yanına soru işareti koyduk, birden fazla esere ve müellife ait olabilecek kitap isimlerine müellif yazmadık. Lutfi Paşa bazen eser adı yazmadan bir müellife atıf yapmaktadır, bu müellifin hangi eserine atıf yaptığını bilemediğimiz durumlarda bu atıfları dikkate almadık, atfın hangi esere ait olduğuna dair kanaatimiz oluştuğu takdirde bu eserin ismini yazdık.

Bu liste, müellifin adını zikrettiği bütün eserlerin eksiksiz bir listesi olduğu iddiasında değildir. Daha ayrıntılı ve ince bir taramanın, bu listeyi zenginleştirmesi kuvvetle muhtemeldir.

\section{Lutfi Paşa'nın Kaynakçası}

- Ebu Cafer Kisâî, Acâibüll-Melekût (Risâletüll-Kunûz fî Letâifi'r-Rumûz, 70a)

- Ali b. Mahmud el-Bedahşanî, Ahlasü'l-Hâlisa (Risâle finn-Niyye, 153b, 154a)

- Şeybânî, el-Asl (Zübdetül-Mesâil, 7a)

- Sühreverdî, Avârifül-Maârif(Zübde, 222b; Kunûz, 9b, 30b, 44a, 61a, 62b)

- Kâsânî, Bedâyi'u's-Sanâyi' (Zübde, vr. 8a, 13b, 14a-b, 15a-b, 57b, 67a, 106b; 172b; Kunîz, 11b, 20a, 49b, 70a)

- Ebu'l-Leys Semerkandî, Bustanu'l-Ârifin (Kunûz, vr. 6a, 29b, 46a, 48b, 50b, 63a; Niyye, 154b)

- Kerhî, el-Câmi', (Zübde, 32a)

- Kurtubî, el-Câmi' li-Abkâmi’l-Kur'an, (Kunûz, 30a)

- Câmiúl-Fetva, (Zübde, 8b, 9a, 22a, 40b, 49a, 204a, 206a)

- Şeybânî, el-Câmiu'l-Kebîr (Tenbîhül-Âkılîn ve Te’kîdül-Gâfilîn (Kürkçüoğlu), 45a)

- Şeybânî, el-Câmi u's-Să̆î̀ (Zübde, 13b, 31a, 48a, 175b, 224a; Tenbîh, 55b; Kunuิz, 36b, 49b)

- Ebu'l-Fazl Rükneddin Kirmânî, Cevâhirül-Fetâvâ (Zübde, 16b, 17a, 49a, 77b, 175a; Kunîz, 42a)

- Cevâhir-i Salât (Tenbîh, 24a)

- Cevâmiu'l-Abkâm (Zübde, 122a)

- Molla Hüsrev, Dürerül-Hükkam (Zübde, 101a)

- ed-Dürrü'l-Manzûm (Zübde, 194b-195a, 197a, 198a) 
- Âmidî, Ebkârül-Efkâr (Zübde, 217a; Kunûz, 42b)

- Hassâf, Edebü'l-Kâdî̀ (Kunîz, 25b)

- Necmeddin Tarsusî, Enfa úl'-Vesâil ilâ Tahrîri'l-Mesâil (Zübde, 82a)

- Beyzâvî, Envâaüt-Tenzîl ve Esrârüt-Tèvîl (Kunûz, 44b)

- Debûsî, el-Esrâr fi'l-Fürû̀ (Zübde, 29a)

- Esrâru's-Saâde (Zübde, 94a)

- Attâbî (ö. 586), Fetâvâ-yı Attâbî (Zübde, 14b, 49b, 51a, 65b, 105a, 114a; Hayât-ı Ebedî (Ali Emiri) vr. 95a)

- Hâfızüddin Muhammed el-Kerderî el-Bezzâzî, Fetâvâ-yı Bezzâziyye (Zübde, vr. 8b, 14a, 17a, 21a, 61b, 184b; Hayât-ı Ebedî 78b, 88a; Kunûz, 9b; 17b, 29a, 30a, 31a)

- Fetâvâ Ebî Cáfer el-Belhî (Zübde, 77b)

- Fetâvâ Ehli Semerkand (Zübde 199a)

- Davud b. Yusuf el-Hatîb, el-Fetâva'l-Gryâsiyye (Zübde, 200b, 221b; Kunûz, 37a)

- Fetâvâ Kâdîhân (Hâniye) (Zübde, 14b, 15a, 16b, 17b, 20b, 49b, 64a, 143b, 180b, 181b, 199a, 201b; Tenbîh 52a; Kunùz, 16b, 17b, 22b, 29a, 31b)

- Ebu Muhammed Siraceddin Ali b. Osman, el-Fetâva’s-Sirâciyye (Zübde, 65b)

- Ferîdüddin Âlim b. Alâ el-Enderpetî, el-Fetâvẩt-Tatarbâniyye (Zübde, vr. 6b, 8b, 9a, 188b, 182a, 190b, 198b, 200b; Hayât-ı Ebedî 67b, 93b; Tenbîh 9a, 10a, 15a, 50a; Kunùz, 8b)

- Zahîrüddin Ahmed b. İsmail Timurtaşî, Fetâvâ et-Timurtâş̂, (Zübde, 45a, 127a, 205a)

- Ebu'l-Feth Abdürreşid b. Ebu Hanife el-Velvâlicî, el-Fetâva'l-Velvâliciyye (Zübde, 182a)

- Fetâvâ-yı Zahîriyye (Zübde, 31a, 47b, 59b, 61b, 86a, 105b, 143a, 166a; Hayât-ı Ebedî vr. 67b; Kunûz,15b, 17a, 28a)

- Abdurrahman Bistâmî, el-Fevâihu'l-miskiyye fi'l-fevâtihi'l-mekkiyye (Halâsü'lümme, 3b)

- Nesefî, Fezâilü̉l-A'mâl (Kunûz, 45a)

- Ebu Hanife, el-Frkhu'l-Ekber (Tenbîh, 28b, 29b, 30a, 31b, 34a-b, 41a, 45a, 51a)

- el-Gunye (İbrahim Halebî, Gunyetül-Mütemellî (?)) (Zübde, 107a; Kunûz, 62b) 
- Hâlisatül-Hakâik (Zübde, 2a; Kunûz, 12a, 14a, 41a, 52a, 53a, 56b, 65a)

- Abdülgaffar b. Lokman el-Kerderî, Hayretül-Fukahâ (Zübde, 84b, 96b, 119a, 124a)

- İbnü'l-Cezerî, Hısnül-Hasîn (Kunîz, 41b)

- Mergînânî, el-Hidâye (Zübde, 21b, 22a, 24a, 30a, 32a, 43b, 47a, 180b;

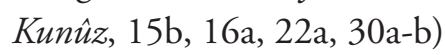

- Ahmed b. Muhammed el-Hanefî, Hizânetül-Fetâvâ (Zübde, 87b)

- Ebu'l-Leys Semerkandî, Hizânetü'l-Fıkh (Zübde, 47a, 82b, 185a, 223a)

- Tahir b. Ahmed el-Buhari, Hulâsâtüll-Fetâvâ (Zübde, 8b, 13a, 16b, 36b, 48a, 102b; Kunuz, 17b, 19a, 27b, 34a, 37a, 45b)

- Hulâsa(tül-Hakâik), (Zübde, vr. 13a; 185a-b; Tenbîh, 39b)

- İbn Hübeyre, el-ífsâh (Zübde, 13b, 14a, 17a, 62a; Kunûz, 21b, 27a)

- Gazzâlî, İhyâu Ulûmi'd-Dîn (Zübde, , 139b; Tenbîh, 31b; Kunûz, 39b, 49a, 50b, 52b, 60b, 61a, 64a)

- Ekmelüddin Bâbertî, el-İnâye Şerhu'l-Hidâye (Zübde, 82a, 101a, 123b, 127a, 129b, 137a-b)

- İbn Ebî Musa (Şerif Muhammed b. Ahmed Hâşimî), el-İrşâd (Zübde, 46b)

- Keykâvus, Kâbusnâme (Tenbîh, 37a)

- Nesefî, el-Kâfî fî Şerhi'l-Vâfî̀ (Zübde, 32a, 41a, 46a, 73b, 106a, 180b, 122a)

- İbnül-Esîr, el-Kâmil fi't-Târih (Zübde, 176b)

- Nesefî, Kenzü'd-Dekâik (Zübde, 32a, 58b, 207a)

- İbnü'l-Ehdel (?), Keşǘl-Gitâ an Hakâiki't-Tevhîd ve Akâidi'l-Muvahhidîn (Zübde, vr. 7b, 190b; Tenbîh, 24a-b)

- Zemahşerî, Keş̧saf (Zübde, 216a; Tenbîh, 14a; Kunîz, 29b)

- Ebu Cafer Mahmud b. Ömer Şa’bî, el-Kifâye fi'l-Fıkh ve’l-Ferâiz (Zübde, 78a)

- Necmeddin ez-Zâhidî, Kunyetüll-Münye li-Tetmîmi'l-Gunye, (Zübde, 77b, 84b, 87b, 101a, 147b; Kunîz, 36b)

- Ebû Tâlib el-Mekkî, Kûtu'l-Kulûb (Tenbîh, 8b)

- Necmeddin Nesefî, el-Manzûmetün-Nesefiyye (Zübde, 87a, 162b)

- Şemsü'l-Eimme el-Halvânî, el-Mebsût (Zübde, 6b, 15b, 26b, 31a, 37a, 45a, 50a, 200b; Kunîz, 24b)

- Serahsî, el-Mebsît (Zübde, 11a, 13a, 18a, 38b, 44b, 111b; Kunîz, 25b, 34a) 
- Ahmed b. Muhammed el-Hanefî, Mecma üll-Fetâvâ (Kunûz, 52b)

- Ahmed b. Musa el-Keşşî, Mecma üll-havâdis vén-nevâzil ve’l-vâkıât (Zübde, vr. 12b, 15a, 189a, 190b; Hayât-ı Ebedî, 94b; Kunûz 6a, 9a, 17b, 32a, 38b; Niyye, 154b)

- Şemseddin el-Halhâlî, el-Mefâtîh fi Halli'l-Mesâbîh (Zübde, 204b)

- Menba'u'l-âdâb (Kunûz, 48a-b, 49a, 50a-b)

- Mesâbihül-Îmân (Tuhfe, vr. 13a, 13b; Tenbîh, 13a, 15a-b, 16a, 45a, 55a)

- Misbâhüd-Dîn (Beyzâvî, Misbâhül Ervâh fî Usûli'd-Dîn (?), Hayât-ı Ebedî 71b; Kunîz, 27b)

- Mişkâtüll-Envâr fî Letâifi'l-Abbâr (Zübde 79a; Risâletüll-Kunûz, 4b; 40b, 44b, 64b, 66a, 67a, 67b)

- Mişkât(ül-Mesâbîh ?/Tebrizî) (Tenbîh, 19a, 49b)

- Burhaneddin Buhârî, el-Muhît (Zübde, vr. 10a, 62b, 75b, 105a-b, 180b, 122a, 142a; Tenbîh 50b; Kunîz, 20b, 25b)

- Radiyyüddin Serahsî, el-Muhît (Kunîz, 29b, 34a-b)

- Muhtârül-Fetâvâ (Zübde, 9a, 86b, 110a; Tuhfe, vr. 15a)

- Mergînânî, Muhtârâtün-Nevâzil (Zübde, 26b, 27a, 153a, 172a, 180b, 181a, 182a-b; Kunûz, 11b, 16a, 20a-b, 21b, 22a, 27a)

- Kudûrî, el-Muhtasar (Zübde, 10a, 11b, 19b, 20b, 30a, 31b, 48b, 73a, 137ab)

- Tahâvî, el-Muhtasar (Zübde, 39b, 120b)

- Hakîm İshak er-Rûmî, Muhtasaru'l-Hikmeti'n-Nebeviyye (Tenbîh, 28b, 29a, 30a-b, 31a, 35b, 41a, 47a)

- Cemâleddin Ahmed b. Muhammed el-Gaznevî, el-MukaddimetülGazneviyye fi'l-Fürûi'l-Hanefiyye (Zübde, 61a, 89a)

- el-Muzmerât, (Zübde, 98b, 178b, 188b; Tenbîh, 57b; Kunûz, 20b, 38b)

- el-Mültekata (Ebu'l-Kasım Semerkandî (ö. 556), el-Mültekat fi'l-Fetâve’lHanefiyye (?) ), (Zübde, vr. , 74b, 180b, 200b, Kunûz, 22a, 28b)

- el-Müntekâ (Zübde, 63b, 162b)

- Yusuf b. Ebu Said Sicistânî, Münyetül-Müftî, (Zübde, 84b, 108a, 187b, 124b, 166a, 175b, 225b)

- Molla Câmi, Nefehâtül-Üns (Tuhfe, 6a; Tenbîh, 54b) 
- Hakîm Tirmizî, Nevâdirü̉-Usûl (Zübde, 200a)

- Ebu'l-Leys Semerkandî, en-Nevâzil (Zübde, vr. 8a-b, 9a, 10a-b, 14b, 198a; Hayât-ı Ebedî, 88b, 93b; Kunûz, 11b, 20a, 21a)

- Siğnâkî, en-Nihâye fî Şerhi'l-Hidâye (Zübde, 59b, 81b, 83b, 86a, 94b, 107b, $123 \mathrm{a}-\mathrm{b}, 142 \mathrm{a}, 174 \mathrm{a})$

- Abdülaziz Nesefî (?), Ravzatün-Nâsıhîn (Kunûz, 13b)

- Hüseyin b. Ali ez-Zendevistî, Ravzatül-Ulemâ (Zübde 89a, 90b; Kunûz, 55b)

- Zemahşerî, Rebîül-Ebrâr (Kunûz, 70a)

- Mustafa b. Hüsam (?), er-Risâletüz-Zevkiyye (Zübde, 91a)

- Seyrüll(Siyerül ?)-Uyûn, (Zübde, 213a)

- Cevherî, Sıhâh (Kunîz, 57b)

- Haddâd, es-Sirâcüll-Vehhâc (Kudûrî şerhi) (Zübde, 16a, 20b, 48a; Kunîz, 24b)

- Şeybânî, es-Siyerül-Kebîr (Zübde, 221b; Kunîz, 33a)

- İsbîcâbî, Şerhu'l-Câmii’s-Săgî̀r, (Zübde, 11a, 172a)

- Şerhu'l-Hakâik el-Manzûme (Zübde, vr. 188a)

- Şerhu'l-Hatîb (Kunîz, 8a, 46b)

- Şerhu'l-Hiyel (li-Hassâf), (Zübde, 205a)

- Şerhu'l-Hutab (Kunûz, 66b, 67b, 69b; Niyye, 155b)

- İbn Melek, Şerhu Mecmai'l-Bahreyn (Zübde, 86a, 100b; Kunûz, 25a)

- Şerhu'l-Mesâbîh (Zübde, 101a; Kunîz, 29b, 35a, 44b, 47b, 53a, 55b, 61a, 67b)

- Şerhu'l-Meşârik (Zübde, 204b; Kunîz, 13a, 42b, 43b, 44a, 47b, 49a, 58b)

- Şerhu Muhtasari'l-Câmi'i'l-Kebîr (Zübde, 108a)

- Hâherzâde Ebu Bekr b. Muhammed el-Buhârî, Şerhu Muhtasari'l-Kudûrî (Zübde, 77b, 127a-b, 128b, 130a)

- Şerhu Muhtasari't-Tahâvî (Zübde, 14a, 21a, 43b, 64a, 84a, 130b, 138a, 182a; Kunûz, 25a, 37b)

- Ebu'l-Leys Semerkandî, Şerhu'l-Mukaddime (Zübde, 107b)

- Şerhu'n-Nukâye (Zübde, 131a; Kunûz, 37b) 
- Serahsî, Şerhu's-Siyeri'l-Kebîr (Zübde, 131a; Hayât-ı Ebedî, 88b)

- Şerhu Şir'ati'l-İslàm (Yahya b. Bahşi / Seyyid Alizâde ?) (Zübde, 173b; Kunûz, vr. 6a, 27a; Tenbîh, 20a, 29b; Niyye, 154a, 155b)

- İbn Melek, Şerhu Tuhfetil-Mülûk (Zübde, 87b)

- Sadrüşşerîa, Şerhu'l-Vikâye (Kunîz, 37a, 48b)

- Kadı İyaz (?), eş-Şifâ, (Kunûz, 31b)

- İmamzâde Muhammed b. Ebi Bekr el-Buhârî, Şir'atül-İslâm (Niyye, 154a)

- Beyhakî, Şu'abül-Î́ân (Tenbîh, 24b)

- eş-Şuhîd (Zübde, 112b)

- Bâbertî, Takrîrül-Usûl, (Zübde, vr. 2b; 185b)

- Zernûcî, Ta lîmül-Müteallim (Kunûz, 41a)

- Cürcânî, et-Ta'rîfât (Kunûz, vr. 6a, 25a, 27b; Niyye, 153b)

- Zahîrüddin Muhammed Hârezmî el-Abbâsî, Tarihu Hârezm, (Zübde, 104a)

- Sadrüşşerîa, et-Tavzîh Şerhu't-Tenkîh (Kunûz, 8b)

- Mergînânî, et-Tecnîs ve’l-mezîd fi'l-fetâvâ, (Zübde, 216b)

- et-Tecrîd (Zübde, 9b)

- Ebu'l-Leys Semerkandî, Tefsir (Kunûz, 41b)

- Fahreddin Râzî, et-Tefsîrül-Kebîr (Hayât-ı Ebedî, 55b)

- Ömer Nesefî, Tefsîr-i Nesefì (et-Teysîr fît-Tefsîr), (Tenbîh, 29a)

- et-Tehzîb (Zübde, 119b).

- Ebu İshak Şîrâzî, et-Tenbîh (Zübde, 144a)

- Ebu'l-Leys Semerkandî, Tenbîhüll-Gâfilîn (Zübde, vr. 183b; Kunûz, 15b; 40a)

- et-Tenvîr (Kunûz, 39b, 41a, 61b, 63b)

- Münzirî, et-Tergî́b ve’t-Terhîb (Zübde, 88b; Kunûz, 14a, 15a)

- Burhaneddin Buhârî, Tetimmetü'l-Fetâvâ (Zübde, 82b, 151b; Hayât-ı Ebedî,, $67 b, 68 a)$

- Zeynüddin Bağdâdî, Tevfîku'l-İnâye fî Şerhi Vikâyeti'r-Rivâye, (Zübde, 12a, 14a, 17b, 22a, 36b, 40b, 126a, 129a, 133b, 140a, 228b)

- Kurtubî, et-Tezkire li-Ahvâli'l-Mevtâ ve Umûri'l-Âhire, (Kunûz, 67a, 68b, 69b, 70a) 
- Alâeddin Semerkandî, Tuhfetül-Fukahâ (Zübde, 137a)

- Tuhfetül-Mülîk (Nesefi / Zeynüddin er-Râzî ?) (Zübde, 13a-b, 38b, 223a, Kunûz, 30a)

- Fahrü'l-İslâm Pezdevî, Usûl (Kenzüll-Vusûl), (Zübde, 123b, 124a; Tenbîh, 35a, 38a, 41b, 44b, 47a; Kunîz, 8b)

- Serahsî, el-Usûl (Tenbîh, 44a)

- Uyûnül-fetvâ (Zübde, 213a)

- Ebu'l-Leys Semerkandî, Uyûnüll-Mesâil (Zübde, vr. 180b)

- Nâtıfî, el-Vâkıât (Zübde, 184b; Hayât-ı Ebedî, 92a)

- Şemsüleimme el-Halvânî, el-Vâkı ât (Zübde, 61b)

- el-Vâki ât (Nâtıfî / Sadrüşşehîd (?)), (Zübde, 142a)

- Ebu Hanife, el-Vasiyye (Zübde, 6a; Kunûz, vr. 4b; Tenbîh, 22a, 28b, 48b)

- Burhaneddin Buhârî, el-Vecîz fi'l-Fetâvâ (Zübde, 57b)

- Zeynüddin el-Hâfî, el-Vesâyâ el-Kudsiyye (Kunûz, vr. 6b; Niyye, 155a)

- Burhânuşşeria, el-Vikâye (Zübde, 52b, 227a)

- Vusîlül-Fıkh (Zübde, 125a)

- Ebu Abdullah Reşîdüddin Mahmud b. Ramazan er-Rûmî, el-Yenâbî fî Ma'rifeti'l-Usûl ve't-Tefârî‘ (Zübde, 54a, 60a, 110a, 178a)

- Necmeddin ez-Zâhidî, Zâdü'l-eimme fî fezâili hasîsati'l-ümme (Zübde, 164a)

- Ahizade Yusuf Efendi, Zahîretü'l-Ukbâ fî Şerhi Sadriş̧serîati'l-Uzmâ (Zübde, 73a, 108a, 133a, 199b, 211b, 219b; Hayât-ı Ebedî, vr. 88b, 90a)

- Şeybânî, ez-Ziyâdât (Zübde, 31a, 74b)

Lutfi Paşa'nın kaynakçası incelendiğinde, Hanefî fıkıh kitapları bakımından çok zengin olduğu, hatta müellifin yaşadığı devirde mütedavil olan belli başlı Hanefî kitaplarını içine aldığı farkedilecektir. Lutfi Paşa’nın yer yer diğer mezheplere ait kitaplara da referans verdiği, mesela Şâfiî mezhebinin muteber muhtasar kitaplarından Şîrâzînnin et-Tenbîh’i ile Hanbelî mezhebine ait İbn Ebî Musa'nın el-írşâd adlı kitabının da listede yer aldığı görülmektedir.

Lutfi Paşa'nın eserlerinde en çok atıf yaptığı çalışmalarım başında şunlar gelir: Tatarhâniyye, Bezzâziyye, Hulâsâtül-Fetâvâ, en-Nevâzil, Mecma'il-havâdis 
vén-nevâzil ve'l-vâkıât, Şerhu Şir'ati'l-İslam, Cevâhirül-Fetâvâ, Muhît-i Burhânî, Bedâyiu's-Sanâyi. Paşảnın telifatı içerisinde bu eserlere yüzlerce atıf vardır. Bu zikredilenler başta olmak üzere listede yer verilen eserlere müellifin yaptığı çok sayıda atıftan yalnız örnekleme kabilinden birkaç atıf gösterilmiştir.

Muhtemelen günümüze ulaşmayan Târihu Hârezm ${ }^{104}$ ve Halvânîn nin Vâkııât 1 gibi bazı eserleri kullanması da onun çalışmalarının kıymetini artıran bir unsur olarak görülebilir.

\section{Sonuç}

Lutfi Paşa'nın İslâmî ilimlerle ilgili eserlerinin büyük bölümü günümüze ulaşmasına rağmen bunlar şimdiye kadar dikkate alınıp incelenmemiş, Tevârib’teki listesiyle Gelibolulu Âlînin kendisi hakkındaki yargıları tekrar edilmekle yetinilmiştir. Bu çalışmamız Paşa’nın eserlerinin önemine dikkat çekmekte ve bu eserler üzerinde farklı disiplinlerin bakış açısıyla çalışmalar yapılması gerekliliğini ortaya koymaktadır. Onun İslâmî ilimlerle irtibatını, eserlerinde atıf yaptığı kaynakları tespit etmek suretiyle göstermeye çalıştık. Kendisine nispet edilen kanunnamenin Âsafnâméden başka bir eser olmadığı da çalışmamızın ortaya koyduğu bir diğer husustur. Lutfi Paşa’nın kariyeri; Osmanlı eğitim sisteminin medrese dışı imkânları üzerinde düşünmek, devşirme kökenli olup yüksek mevkilere gelen ve ilmî bakımdan da kendini yetiştiren başka örneklerin olup olmadığını araştırmak için bir vesile olabilir.

\section{Bir İslâm Âlimi Olarak Lutfi Paşa}

Özet — Lutfi Paşa Osmanlı Devleti'nin 16. yüzyılda faaliyet göstermiş önemli devlet adamlarından biridir. Kariyeri boyunca üstlendiği çeşitli resmi görevlerden sonra iki yıl kadar veziriazamlık da yapmıştır. Lutfi Paşa, aynı zamanda çoğu İslâmî ilimlere dair olmak üzere çok sayıda eser kaleme almış velud bir müelliftir. Genellikle Âsafnâme adlı siyasî risalesiyle bilinen Lutfi Paşa’nın yazma halinde kalan İslâmî eserleri şimdiye kadar herhangi bir akademik değerlendirmeye konu olmamıştır. Bu makalede Lutfi Paşa’nın bu yönü üzerinde durulmaktadır.

Anahtar Kelimeler: Lutfi Paşa, İslâmî ilimler, Ehl-i sünnet, akaid, ilmihal, hilafet, kanunname, Âsafnâme

104 Bu bilgiyi kendisinden aldığım Prof. Dr. Cengiz Tomar'a müteşekkirim. 


\section{Kaynakça}

Abdüssamed Abîdî, Hazâinül-Kânun, Süleymaniye Kütüphanesi, Lala İsmail, 412.

Abou-el-Haj, Rifa'at Ali, Modern Devletin Doğası (çev. Oktay Özel-Canay Şahin), İstanbul: İmge, 2000.

Atik, Kayhan, Lütfi Paşa ve Tevârih-i Âl-i Osman, Ankara: Kültür Bakanlığı, 2001.

Ayn Ali Efendi, Kavânîn-i Âl-i Osman, İstanbul: Tasvîr-i Efkâr Gazetehanesi, 1280.

Bassano, Luigi, Kanuni Dönemi Osmanlı İmparatorluğu’nda Gündelik Hayat (çev. Selma Cangi), İstanbul: Yeditepe Yayınevi, 2015.

Bursalı Mehmed Tahir Bey, Osmanlı Müellifleri, İstanbul: Matbaa-i Âmire, 1333.

Celâlzâde Mustafa, Tabakâtül-Memâlik ve Derecâtüll-Mesâlik (Geschichte Sultan Süleyman Kanunis von 1520 bis 1557), nşr. Petra Kappert, Wiesbaden: Franz Steiner Verlag, 1981.

Develi, Hayati, “'Lütfi Paşa ve Tevârih-i Âl-i Osman’ Üzerine”, İlmi Araştırmalar 14, İstanbul 2002, s. 247-254.

Ertaş, Kasım, Gelibolulu Mustafa Âlînin Nasîhatü̉s-Selâtîn İsimli Eserinin Tenkidli Metni (yüksek lisans tezi), İstanbul 2008.

Evliya Çelebi, Seyahatname, İstanbul: İkdam Matbaası, 1314.

Fleischer, Cornell, Tarihçi Mustafa Âli, İstanbul: Tarih Vakfı Yayınları, 2001.

Fodor, Pál, “Macaristan’a Yönelik Osmanlı Siyaseti, 1520-1541”, çev. Özgür Kolçak, $\dot{I}_{s-}$ tanbul Üniversitesi Edebiyat Fakültesi Tarih Dergisi, 40 (2004).

Gökbilgin, M. Tayyip, "Lutfi Paşa”, İA, VII, 96-101.

İpşirli, Mehmet, "Lutfi Paşa”, DİA, XXVII, 234-236.

Kâtib Çelebi, Keşǚz-Zunûn, İstanbul: Milli Eğitim Bakanlığı, 1972.

....., Süllemü̉l-Vusûl ilâ Tabakâti'l-Fuhûl, İstanbul: İslam Tarih, Sanat ve Kültür Araştırma Merkezi (IRCICA), 2010.

Köksal, Asım Cüneyd, Fıkıh ve Siyaset, İstanbul: Klasik Yayınları, 2016.

....., “Taşköprîzâde’de Akıl, Siyaset ve Tarih” Insan ve Toplum, 7/1 (2017), s. 233-247.

Köprülü, Fuat, "Lutfi Paşa”, Türkiyat Mecmuası, 1925, sy. 1, s. 118-150.

Kütükoğlu, Mübahat, Lutfi Paşa Âsâfnâmesi: Yeni Bir Metin Tesisi Denemesi, İstanbul: İstanbul Üniversitesi Edebiyat Fakültesi, 1991.

Lutfi Paşa, Âsafnâme, Süleymaniye Ktp., Laleli, 3737.

....., Hayât-ı Ebedî, Millet Kütüphanesi, Ali Emiri, 257; Süleymaniye Kütüphanesi, Hacı Mahmud Efendi, 1524.

....., Halâsüll-Ümme fî Ma'rifetill-E’imme, Süleymaniye Kütüphanesi Ayasofya 2877, 2876. 
....., Halâsüll-Ümme fì Ma'rifeti'l-E'imme, nşr. Mâcide Mahlûf, Kahire: Dâru'l-Âfâki'lArabiyye, 2001.

....., Kânûn-ı Benı̂ Osman el-Ma'rûf bi-Âsâfnâme, nşr. Luvis Şeyho, Beyrut, Matbaatü’lKatolikiyye, 1911.

....., Risâletü'l-Künûz fî̀ Letâifi'r-rumûz, Süleymaniye Kütüphanesi, Pertev Paşa, 90.

....., Risâle-i Niyyet, Millet Kütüphanesi, Ali Emiri, 257 (vr. 110b-114a).

....., Risâle-i Suâl ve Cevab, Süleymaniye Kütüphanesi, Kılıç Ali Paşa 378 (vr. 64-73); Hacı Mahmud Efendi, no. 6385 (vr. 1-6); Millet Kütüphanesi, Ali Emiri, 257 (vr. 106-110).

....., Tevârih-i Âl-i Osman, İstanbul: Enderun Kitabevi, 1990 (İstanbul, 1341 baskısının tıpkıbasımı).

....., Tenbîhül-Âkılîn ve Te’kîdül-Gâfilîn, Millet Kütüphanesi, Ali Emiri, 257 (vr. 1-52); Süleymaniye Kütüphanesi, Kemal Edip Kürkçüoğlu, 2.

....., Tuhfetüt-Tâlibîn, Süleymaniye Kütüphanesi, Fatih, 1507.

....., Zübdetül-Mesâil, Bayezid Devlet Kütüphanesi, 1985.

Muhyiddin Seydi Çelebi, Ehâdîs Tetéallak bi-Ahkâmi's-Saltana, Süleymaniye Kütüphanesi, Laleli, 639.

Mustafa Âlî, Gelibolulu, Künhüll-Ahbâr, Türk Tarih Kurumu Kütüphanesi yazma nüshası tıpkı basımı, Ankara, Türk Tarih Kurumu Yayınları, 2009.

....., Nushatu's-Selâtîn, haz. Andreas Tietze, Mustafā 'Ālī's Counsel for Sultans, Wien: Österreichischen Akademie der Wissenschaften, 1979.

Müneccimbaşı Ahmed Dede, Müneccimbaşı Tarihi (Sahâifüll-Ahbâr), İstanbul: Matbaa-i Âmire, 1285.

Osmanzade Ahmed Tâib, Hadîkatü'l-Vüzerâ, İstanbul, 1271.

Öz, Mustafa (çev.), İmâm-ı Azam’ın Beş Eseri İstanbul: İFAV, 1992.

Özergin, M. Kemal, Sultan Kanuni Süleyman Han Çağına Ait Tarih Kayıtları, Erzurum, 1971.

Peçevî İbrahim, Tarih-i Peçevî, İstanbul: Matbaa-i Âmire, 1283.

Sehî Bey, Heşt Bihiş̧, haz. Günay Kut, yay. Şinasi Tekin ve Gönül Alpay Tekin, Harvard: Harvard University, 1978.

Şehrîzâde Mehmed Saîd, Tầül-Kavânîn, Topkapı Sarayı Müzesi, Emanet Hazinesi, 2064.

Tayyarzâde Ahmed Atâ, Tarih-i Atâ, İstanbul, 1293. 